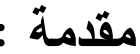

تعتبرُ الطفولة من أهم مر احل حياة الإنسان ، ففي هذه المرحلة تتمو

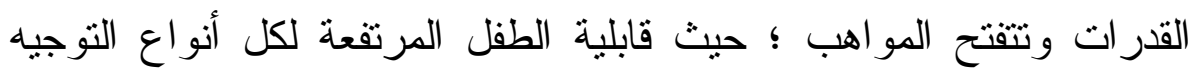

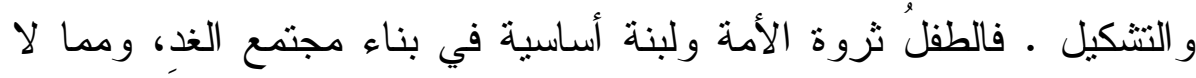

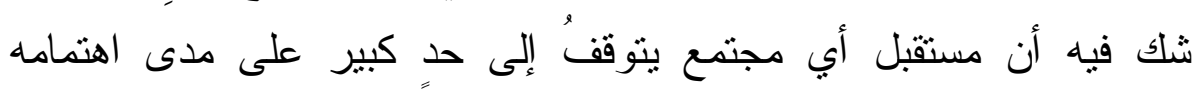

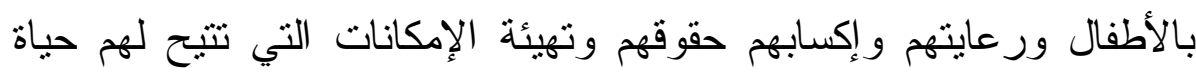

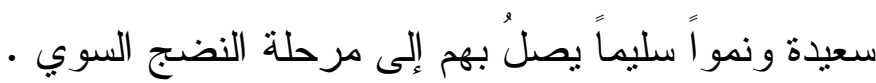

وقد كان المسرح و لا يزال أحد أهم وأبرز الوسائل التي تســتخدمها

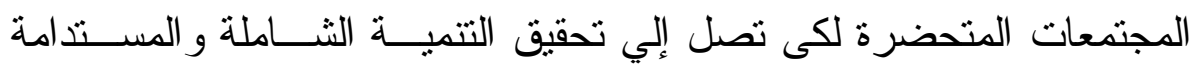

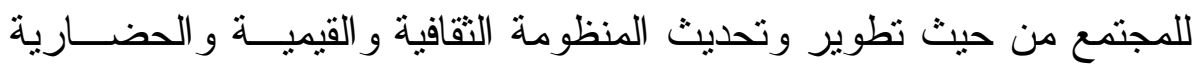

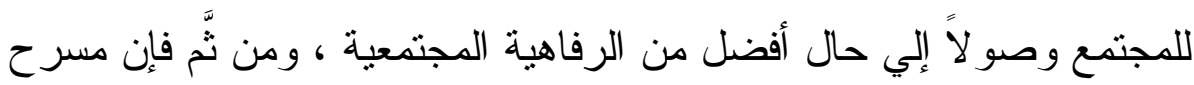

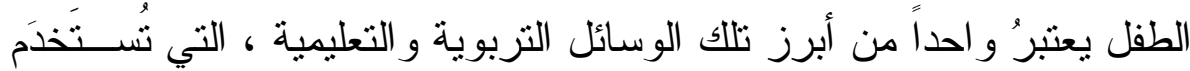

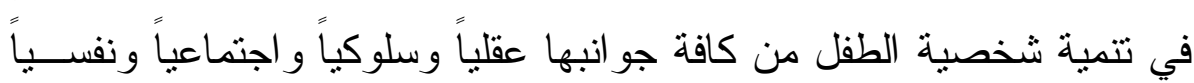

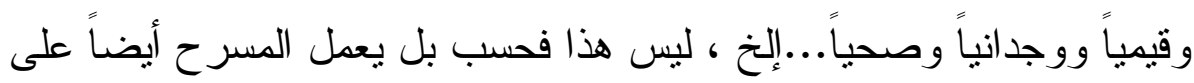

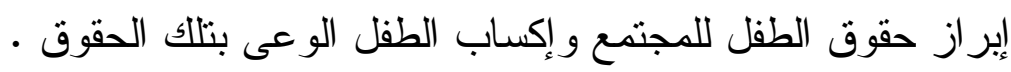

ويُعد " سمير عبد الباقى " فى طليعة كُتاب مسرح الطفل المتميزين ؛

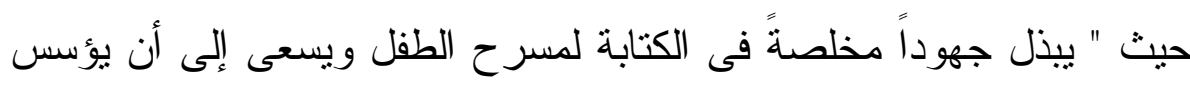

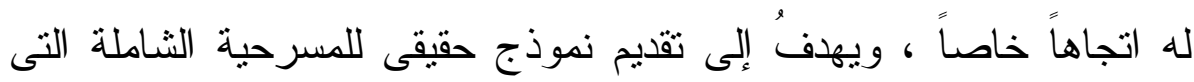

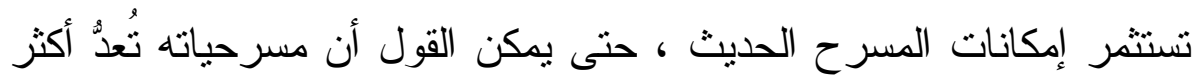

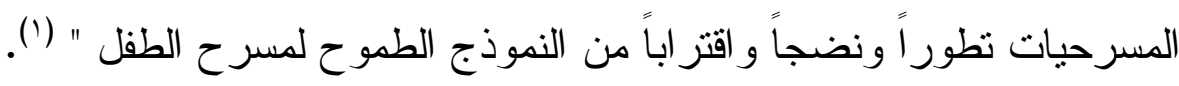


وأُمحر (السير بحمر (السير

وقد كتب " سمير عبد الباقى " العديد من النصوص المسرحية النى

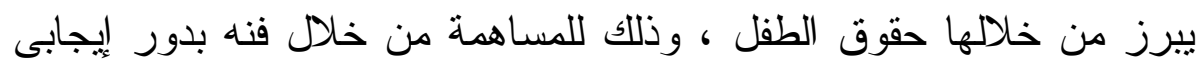

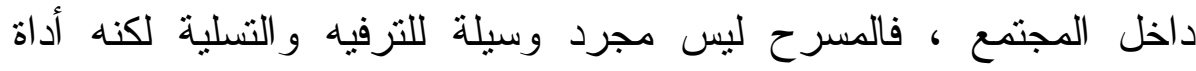
تتويرية للفكر و الوعى ونهضة المجتمع فى شتى مجالاته المتعددة سواء الثقافية والاجتماعية و السياسية ، ووعى وتتوير الطفل بحقوقه أحد منطلبات

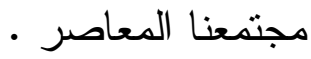
مشكلة الدر اسة وتساؤلاتها : نبعت مشكلة الدراسة من خلال قر اءات الباحث ، حيــث وجـــــ أن

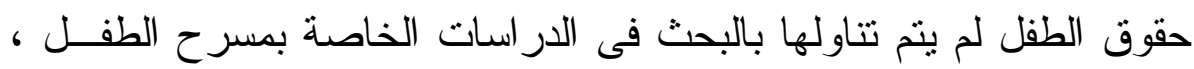

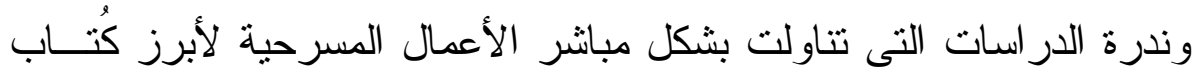

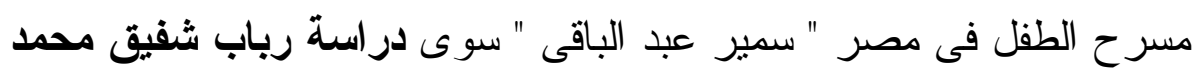

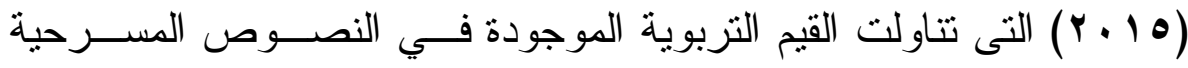

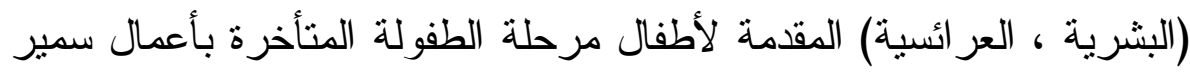

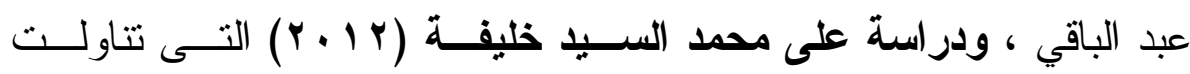

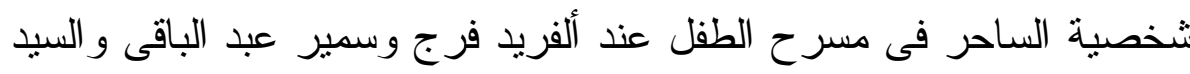
حافظ ، لذلك فإنه من الطبيعى أن نتتاول بالبحث و التحليل الأعمال المسرحية

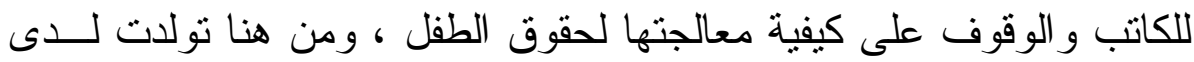

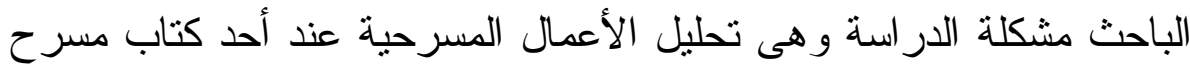
الطفل المعاصر الكاتب المسرحى " سمير عبد الباقى " . ومما سبق يمكن أن تتبلور مشكلة الدراسة فى السؤال الرئيس الأتى: ما حقوق الطفل فى مسرح " سمير عبد الباقى " ؟ . . وينبثق من هذا السؤ ال الرئيس عدة تساؤ لات فرعية هى :

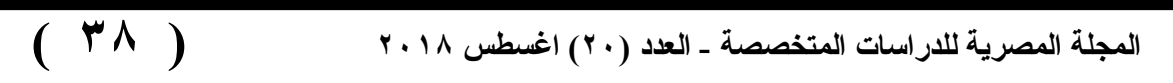




\section{حقوق الطفل فى مسرح "سمير عبد الباقى"}

1- 1 ما مفهوم حقوق الطفل ؟ .

ץ- ما هى حقوق الطفل فى الثريعة الإسلامية و الدو اثثق الدولية ؟ r- ما أبرز حقوق الطفل التى نتاولها " سمير عبد الباقى " في أعماله

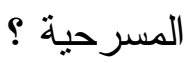

ع - ما طريقة معالجة " سمير عبد الباقى " لحقوق الطفل ؟

أهمية الار اسة :

تتمنلُ أهمبة هذه الدر اسة فى :

1- أهمية حقوق الطفل ذاتها حيث بسعى أي مجتمع لتربية أبنائه عليها

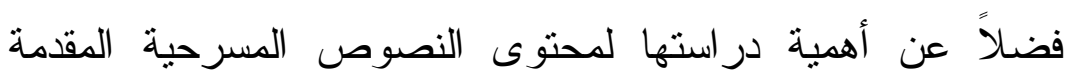
للطفل من خلال المسرح باعتبارها من الكتابات المُهمة الموجهة

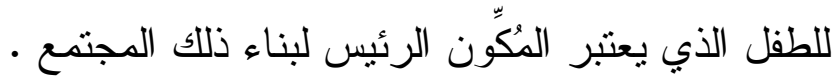
r- إلقاء الضوء على أحد كُتاب مسرح الطفل الذى لم يحظ بقسط و افر من الدراسات ، وذلك من خلال قيام الباحث بتحليل بعض من أعماله

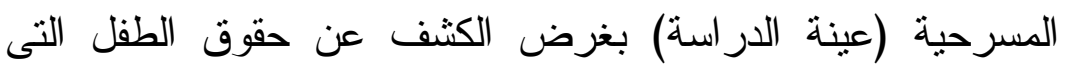
تتاولها "سمير عبد الباقى " فى نصوصه المسرحية . لمنية r- إبراز دور الفن بصفة عامة ومسرح الطفل بصفة خاصة فى المساهمة بدور إيجابى نتويرى داخل المجتمع • أهداف الدراسة : - أل تهدف الدر اسة التعرف على : 1 - التعرف على مفهوم حقوق الطفل . 
وا أُمر السير محمر السير

r- التعرف على حقوق الطفل فى الثريعة الإسلامية و المو اثثق الدولية .

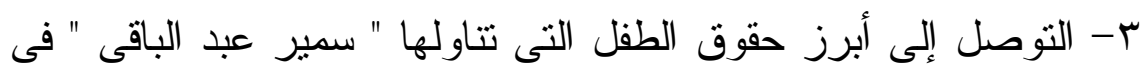

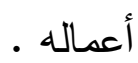

ع- الكثف عن كيفية معالجة " سمير عبد الباقى " لحقوق الطفل فى

نصوصد المسرحية .

منهج الدراسة وأدواتها :

أ- منهج الدراسة :

تعتمد الدراسة على المنهج التحليلى الوصفى .

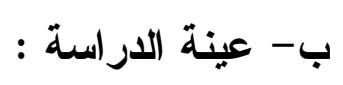

تمثلت عينة الدر اسة فى مجموعة من النصوص المسرحية للكاتب "

سمير عبد الباقى " وهى (أرنب فوق العادة - قرص عسل من غير كسل -

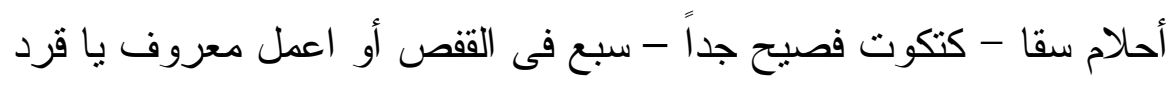

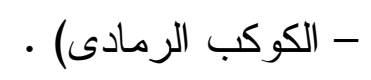

$$
\text { ج- أدوات الاراسة : }
$$

اعتمدت الدر اسة على أداة تحليل المضمون لعينة الدر اسة .

حدود الار اسة :

تتحدد حدود الدر اسة فى الحدود التالية :

1- الحد الموضوعى : حقوق الطفل فى مسرح " سمير عبد الباقى " .

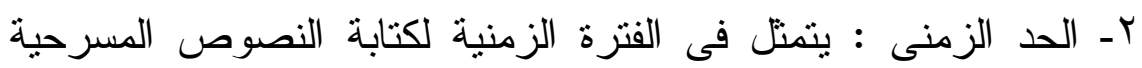

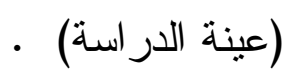

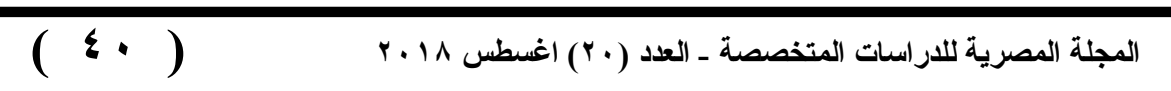


يقوم الباحث بعرض الدراسات السابقة التى ترتبط بموضوع الدراسة

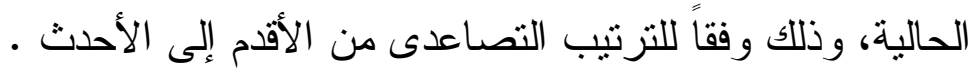

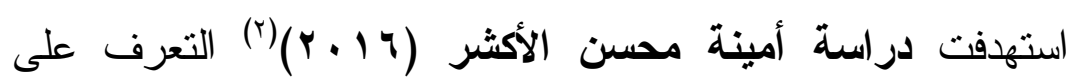

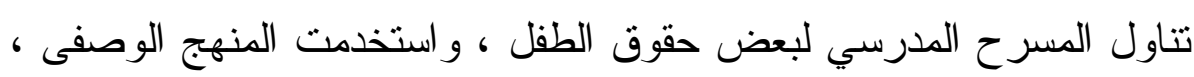

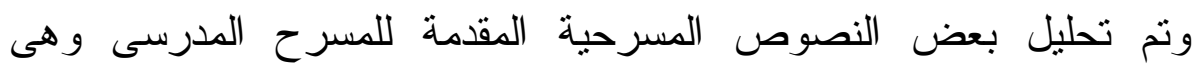

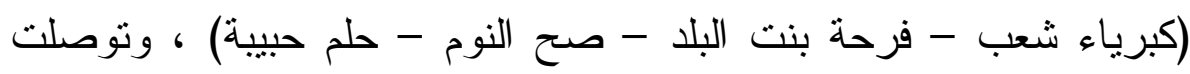
الدراسة إلى أن الخطاب المسرحى فى النصوص المسرحية - عينة الدراسة

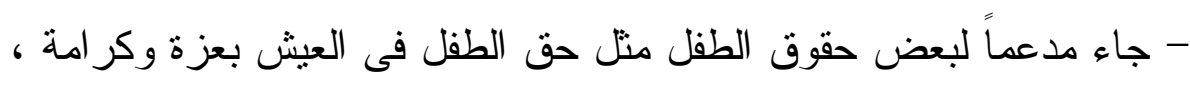
حق اللعب ، الحق فى مستوى اقتصادى وتعليمى مناسب. وقد أثنارت دراسة عزيزة إبراهيم (10 ب (r) إلى دور الإعلام

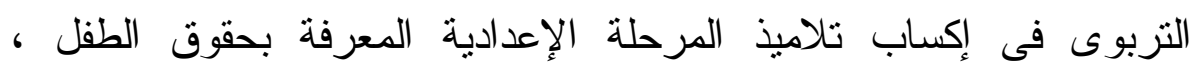
و اعتمدت على المنهج الوصفى ، وطبقت الباحثة استمارة استبيان واستمارة

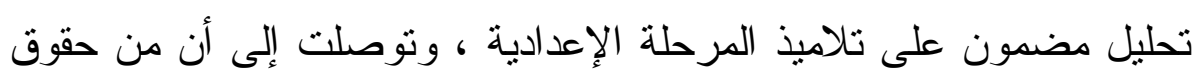

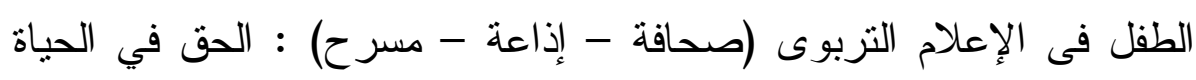

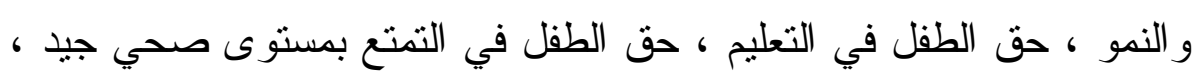

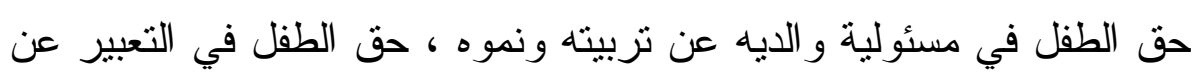

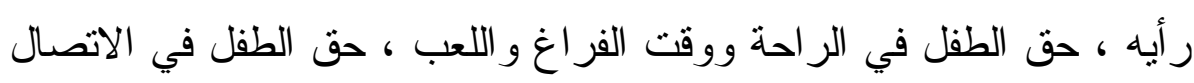

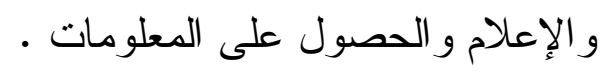
و اهتمت دراسة رباب شفيق محمد (10 ب) (צ) بالتعرف على القيم الثربوية الموجودة في النصوص المسرحية (البشرية ، العرائسية) المقدمة 
لأطفال مرحلة الطفولة المتأخرة بأعمال سمير عبد الباقي ، اعتمدت الدراسة

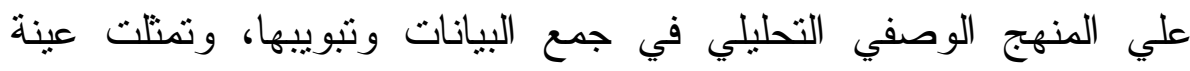
الدر اسة فى ثمانية نصوص مسرحية بطريقة عمدية ومناسبة لمرحلة الطفولة

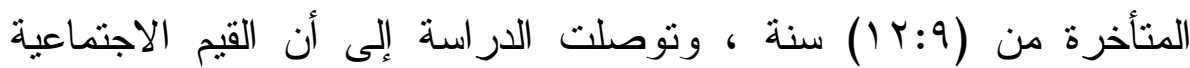

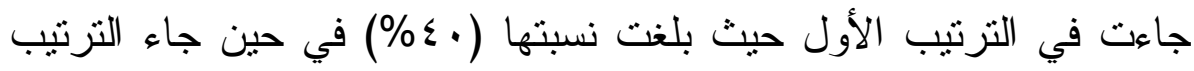

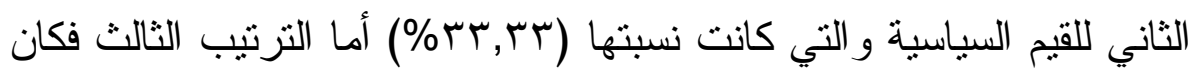

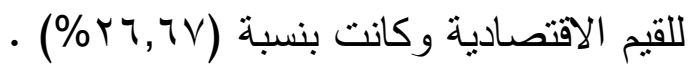

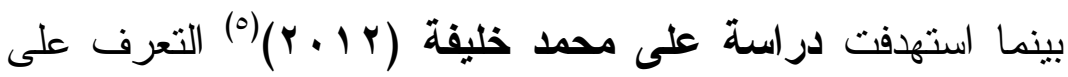
شخصية الساحر فى مسرح الطفل عند ألفريد فرج و سمير عبد الباقي و السيد

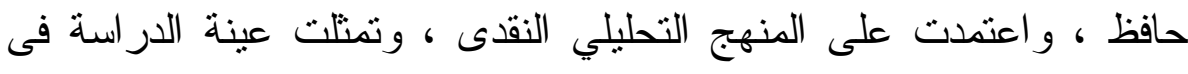

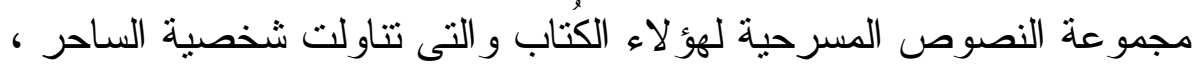

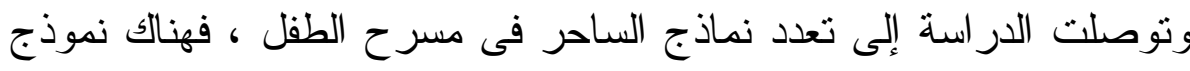

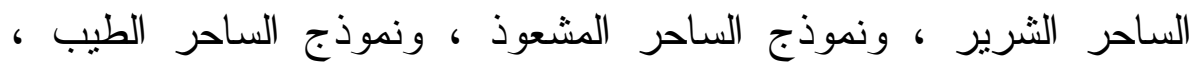

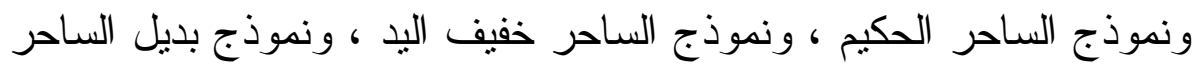

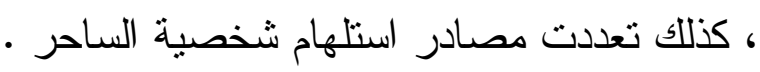

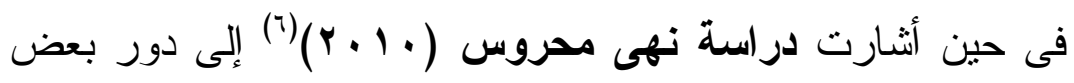
المسرحيات المقدمة على مسرح الطفل في إثباع بعض احتياجات الطفل

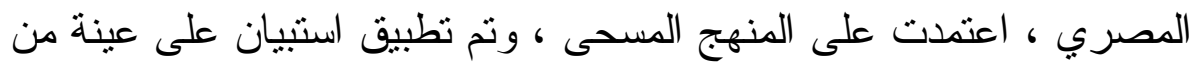

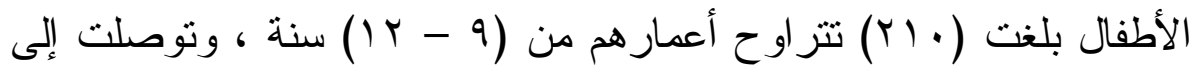

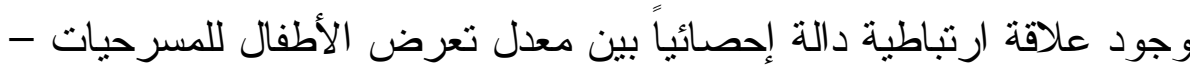

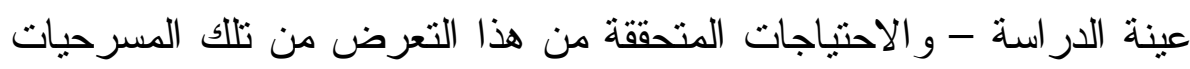
، وقد حققت المسرحيات إثباعات اجتماعية وصحية للأطفال .

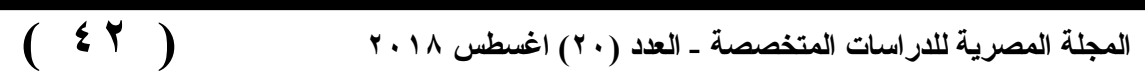


واهتمت دراسة سوسن رسلان (r. . . (r) بالتعرف على وسائل

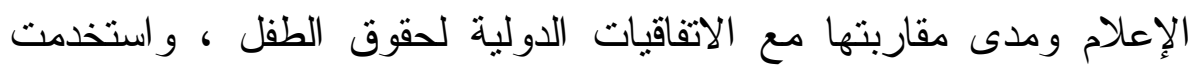

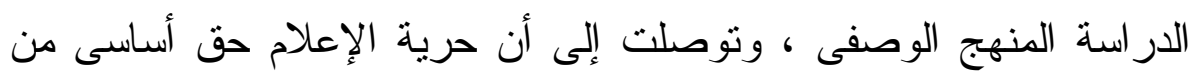

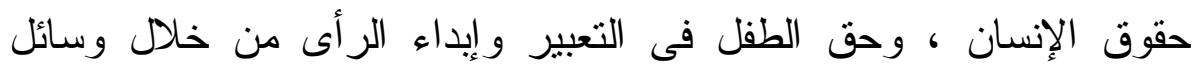
الإعلام ، وكذللك حقه فى الحصول على المعلومات .

التعليق على الدراسات السابقة :

$$
\text { أولاًا / من حيث الهذف : }
$$

استهدفت بعض الدراسات التعرف على حقوق الطفل فى وسائل الإعلام المختلفة (إذاعة - صحافة - مسرح) منل دراسة عزيزة إبراهيم

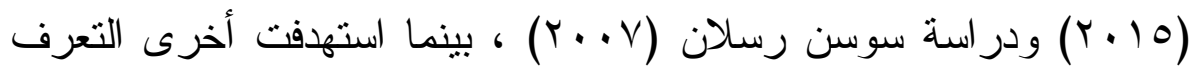
على حقوق الطفل فى المسرح بصفة خاصة مثل در اسة أمينة محسن الأكثر

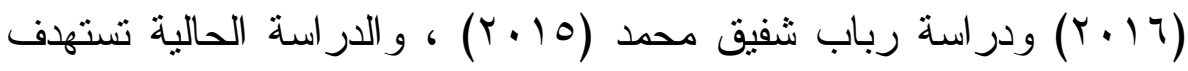
التعرف على حقوق الطفل فى مسرح " سمير عبد الباقى " . ثنانياً / من حيث المنهج :

اعتمدت معظم الدراسات على الدنهج الوصفى التحليلى ، وهو

المنهج الذى اتبعه الباحث فى الدر اسة الحالية .

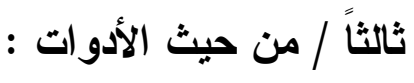

طبقت بعض الدراسات استمارة استبيان مثل دراسة نهى محروس

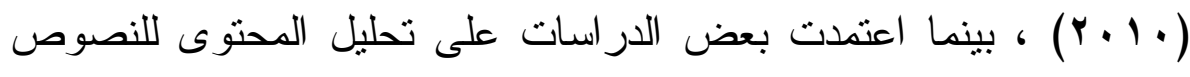

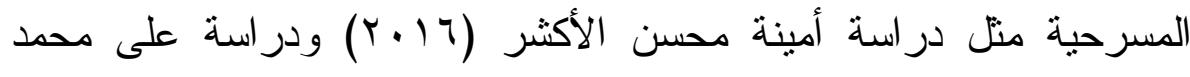

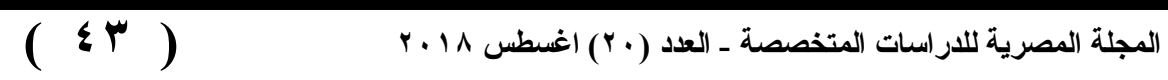


وا أمحر (السير لحمر (السير

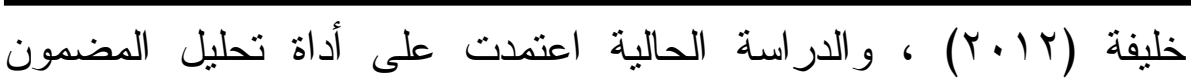

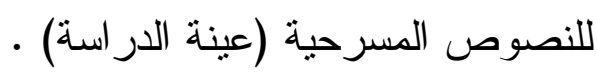

\section{رابعاً / من حيث النتائج :}

توصلت معظم الدراسات إلى عدة حقوق للطفل تتمتل فى الحق في

الحياة والنمو ، حق الطفل في التعليم ، حق الطفل في التتنع بمستوى صحي جيد ، حق الطفل في مسئولية والديه عن تربيته ونموه ، حق الطفل في

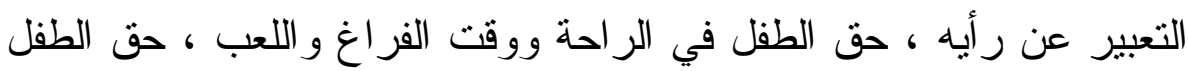
في الحصول على المعلومات . أوجه الاستفادة من الدر اسات السابقة : 1- التحديد الدقيق لمشكلة الدر اسة والإطار العام للبحث . r- التأصيل النظرى لمتغير ات الدر اسة .

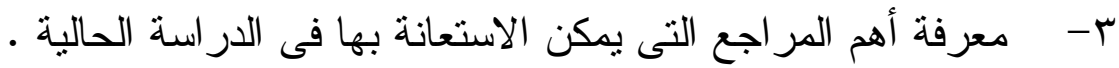

\section{مصطلحات الاراسة : - مصات}

1- حقوق الطقل : " هى مجموعة كاملة من حقوق الإنسان المدنية

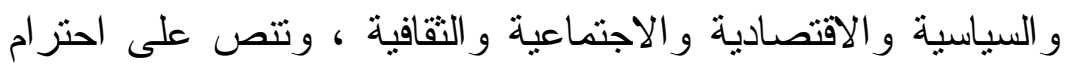
وحماية حقوق الأطفال وهى نقطة الانطلاق لتحقيق التتمية الكاملة

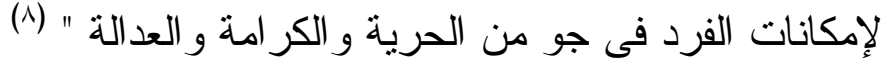
ويعرفها الباحث إجرائياً وفقاً لطبيعة الدراسة بأنها : مجموعة الحقوق المُتضنَنَة بنصوص مسرح حالطفل عند " سمير عبد الباقى " . r- مسرح الطقل : " هو المكان المهيأ مسرحياً لتقايم عروض تمثيلية كتبت و أخرجت خصيصاً لمشاهدين من الأطفال. وقد يكون اللاعبون 


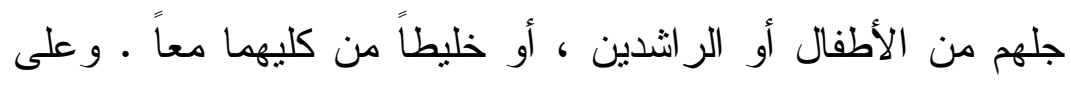

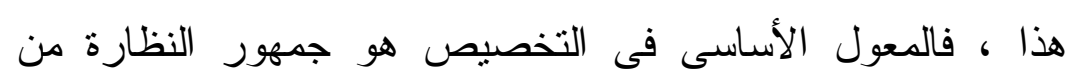

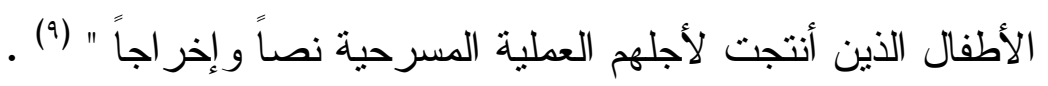

ويعرفه الباحث إجر ائياً بأنه : النص المسرحى الموجه للطفل ويحمل النهل

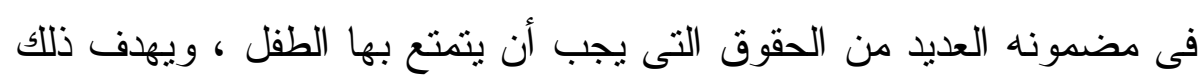
المسرح إلى نتوير الأطفال و المجتمع بحقوق الطفل .

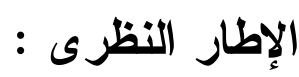

\section{المحور الأول : حقوق الطقل :}

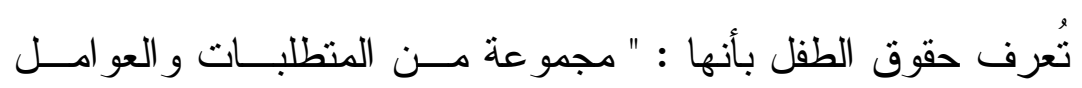
الأساسية و الضرورية الثابتة، التي تدخل في تكوين الطفل الجسدي و النفسـيـي فئسي

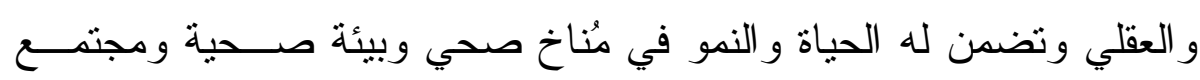

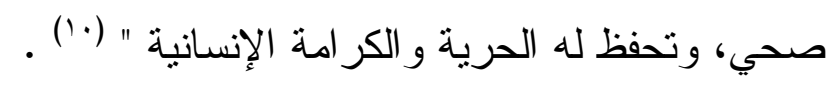
ويمكن تعريف حقوق الطفل بأنها : "عبارة عن مجموعــة الحقـوق

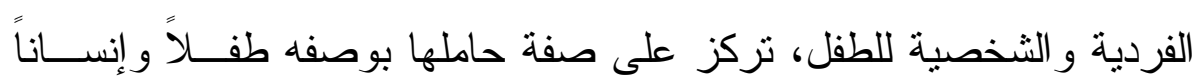
بحاجة للر عاية و العناية. (') وبذللك يمكن إجمالها بأنها " هي مجموعة كاملة من حقوق الإنســان

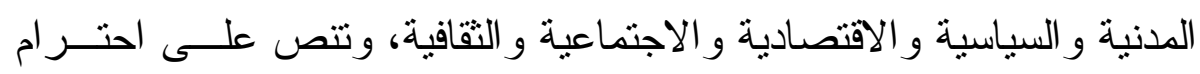

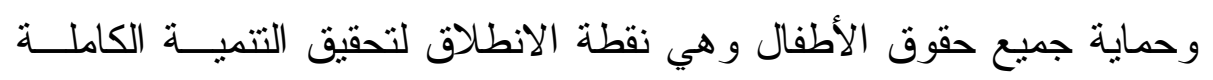

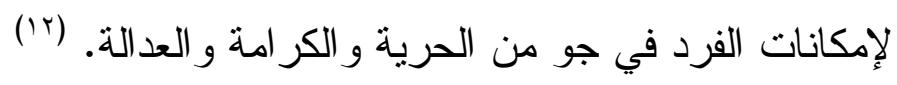


ويرى الباحث أن التعريفات السابقة اتفقت على أن حقوق الطفل جزء

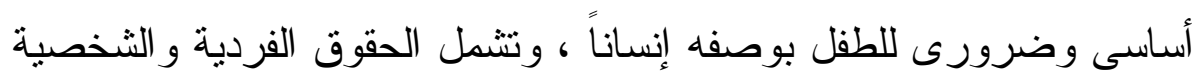

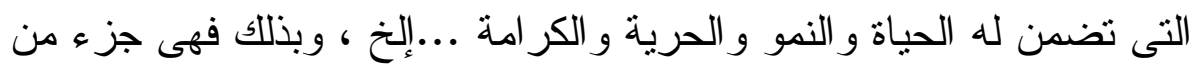
حقوق الإنسان و التى حرص عليها الإسلام و المو اثثيق الدولية كما يلى : أولاً : حقوق الطقل في الإسلام :

كان الإسلامُ أول نظام اجتماعي يقررُ ويحمي حقوق الإنسان العامة

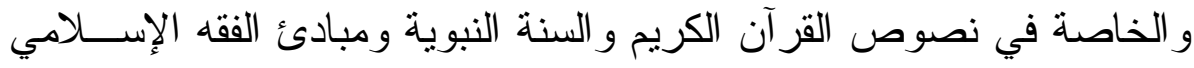

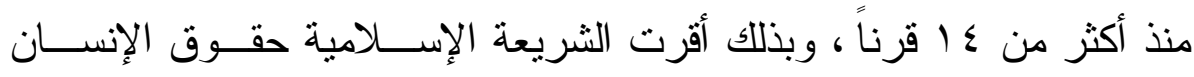
و الطفل قبل المواثيق الدولية بحقبة طويلة اعتبرتها من الواجبات الثـــرعية،

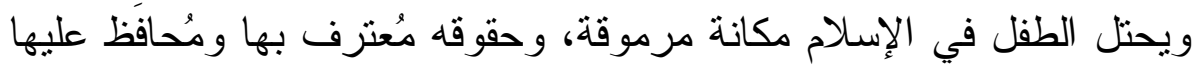
بنص القرآن الكريم و الحديث، حيث وضع الإسلام نظاماً محكماً ودقيقاً للطفل

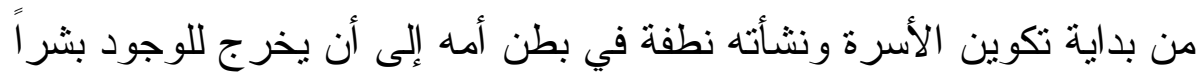

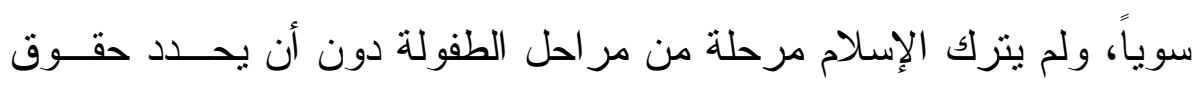

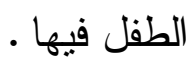

ومن ملامح رعاية الطفولة في الإسلام الآتي (r') :

- أبقى الإسلام على المظاهر الإيجابية التي كانت سائدة قبل بعث النبي إم كتدريب الطفل على الفروسية. - ألغى الإسلام المظاهر السلبية التي سادت قبله في معاملـــة الأطفــال

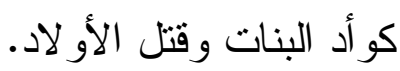

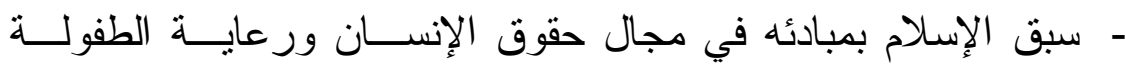
التشريعات الوضعية التي جاءت بعده بمئات السنين لتؤكد ما أكده. 


\section{حقوق الطقل فى مسرح "سمير عبد الباقى"}

وقد وضع الإسلام القو اعد الثابتة لحماية حقوق الطفل بكامل جو انبها،

وفي مختلف مر احل الطفولة حيث ضمن للطفل حقه في الحياة، والرضاعة، و الحضانة، وألغى التمييز بين الأطفال بكافة صوره، وضمن حق الطفل في الإرث، و أكد على التعامل الرحيم مع الأطفال .

وقد ضمنت الثريعة الإسلامية للطفل و أكــــت لــهـ علــى الحقــوق

- التأكبد على حق الطفل في الصحة و الحياة. - حق الطفل في الأسرة و النسب و الاسم و الملكية و المبر اثل. - - حق الطفل في الرعاية الصحية و التغذية السليمة. - مق الطفل في التعليم و اكتساب المهار ات. ثانياً : حقوق الطقل في المواثيق الدولية :

\section{أ-إعلان جنيف عام ؛ 9 ا 19}

" وفقاً لديباجة الإعلان المكون من خمسة بنود ، فإن الرجال و النساء

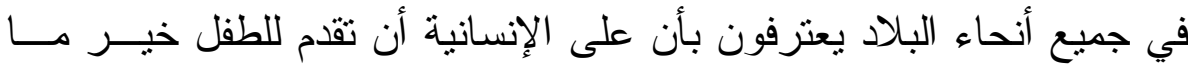

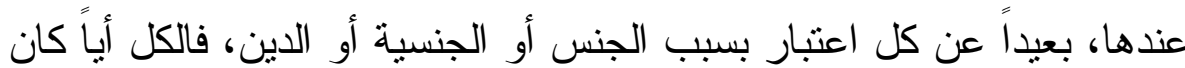

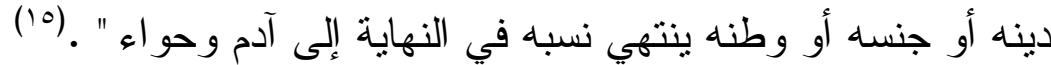

وأما مبادئ الإعلان تلخص في الآتي :(1) 1- ضرورة أن يكون الطفل في وضع يمكنه من النمو على نحو عادي من الناحيتين المادية و الروحية. 


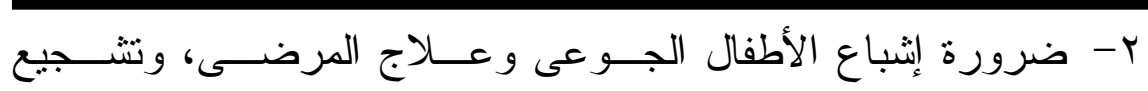
المتخلفين، وأن يعاد الطفل المنحرف إلى الطريق الصحيح، وأن ينت إيو اء و إنقاذ الأطفال الأيتام و المهجورين. r- ضرورة أن يكون الطفل أول من يتلقى المساعدة في أوقات الثدائد.

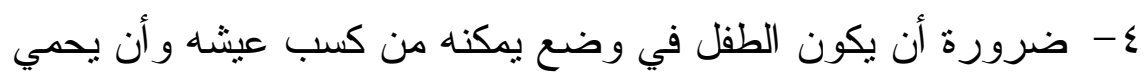

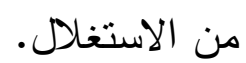
0- ضرورة أن تتم تربية الطفل في أجواء تتمي مسن روح المســئولية عنده.

و على الرغم من أن إعلان جنيف كان هو الخطوة الدولية الأولى في

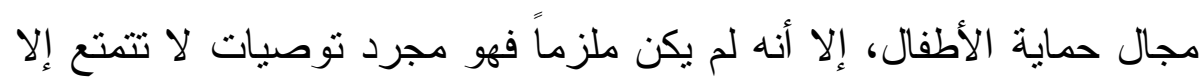

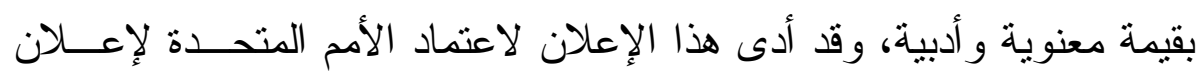

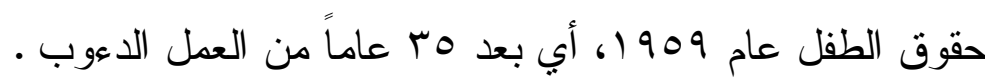

\section{ب-الإعلان العالمي لحقوق الإنسان :}

" صدر الإعلان العالمي لحقوق الإنسان في •( ديسمبر 19 19 بعد

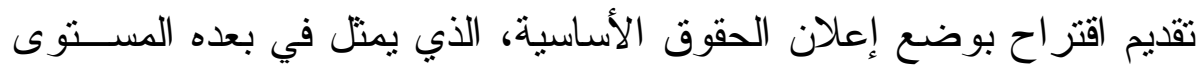

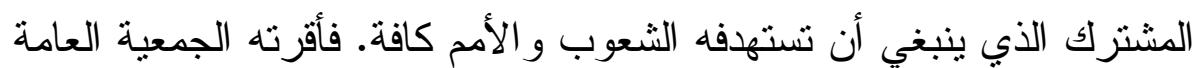
للأمم المتحدة وعكفت على تحويل المبادئ التي جاء بها الإعلان إلى أحكـام

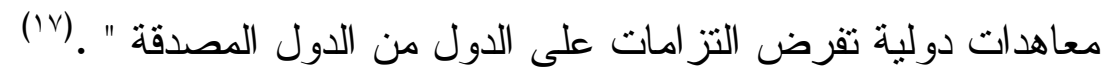

(’): ويمكن تلخيص الحديث حول ميزة هذا الإعلان في الآتي

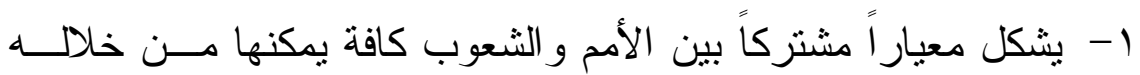
قياس إنجاز اتها على صعيد حقوق الإنسان . 
ץ- تأكيده على ضرورة الاعتر اف بكر امة الكـــائن البثــري، وتفعيـلـ

حمايتها.

r- ضم الإعلان قائمة بالحقوق السياسية و الدننية و الاجتماعية و التقافية

و الاقتصادية .

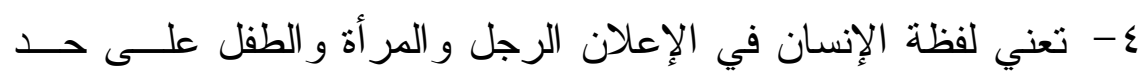

سواء. - ماء.

0- جاء هذا الإعلان ليؤكد على الالتز ام الــدولي بتلبيـة الاحتياجـات

الخاصة بالطفل لإبراز الاختلاف بين عالم الأطفال و عالم البالغين.

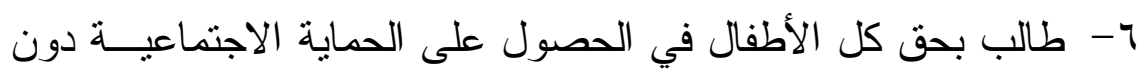

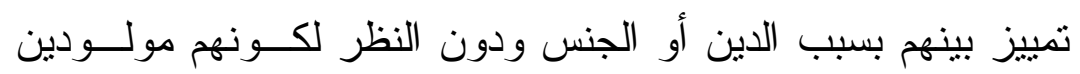

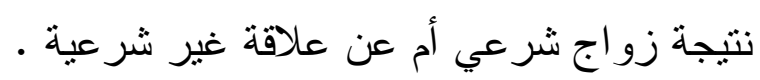

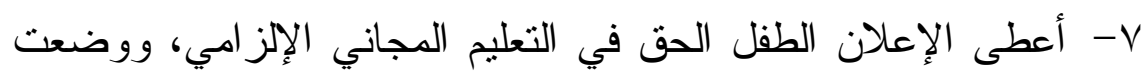

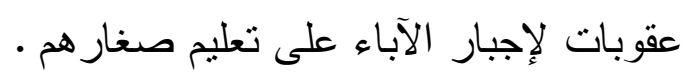

ج--إعلان حقوق الطقل عام 1909 :

أصدرت الجمعية العمومية للأمم المتحدة إعلان حقوق الطفل

في عام 1909 بمو افقة VN دولة من دون معارضة أو امتتاع أي دولة .

أما مبادئ الإعلان تلخص في الآتي : (19)

1- ضرورة أن يتمتع الطفل بالحقوق المقررة في الإعلان من دون تمييز بسبب العرق أو الجنس أو اللون أو الدين أو غير ها.

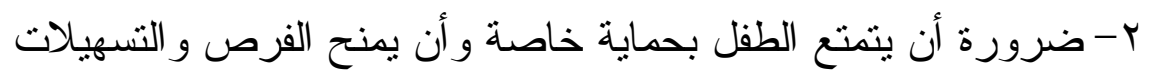

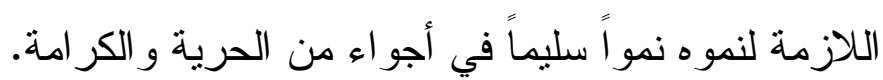


r- أن للطفل منذ و لادته الحق في اسم وجنسية.

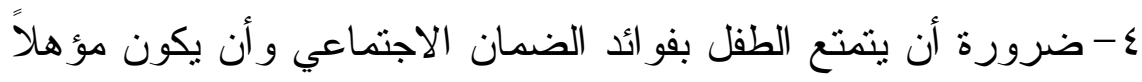

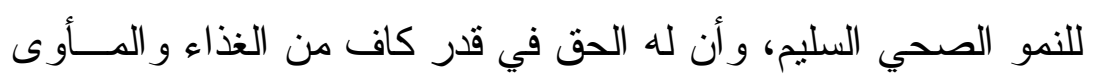
و واللهو و الخدمات الطبية.

ه- ضرورة أن يحظى الطفل المعوق بالمعالجة و التربية و العناية الخاصة

$$
\text { التي تستوجبها إعاقته. }
$$

1- أن تتم تنشئة الطفل برعاية و الديه في جو يسوده الأمن و الحنان، و أن

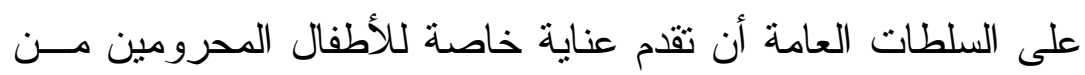

$$
\text { الأسرة و المفتقرين إلى كفاف العيش. }
$$

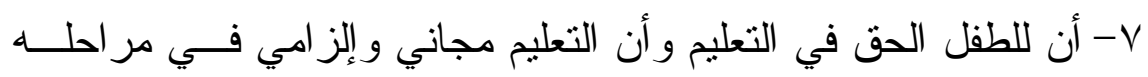

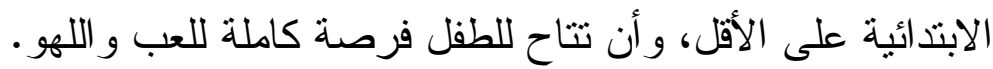
1- أن يكون الطفل بين أو ائل المتمتعين بالحماية و الإغاثة.

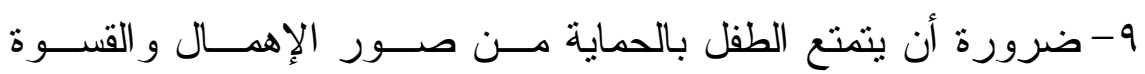

$$
\text { و الاستغلال كافة. }
$$

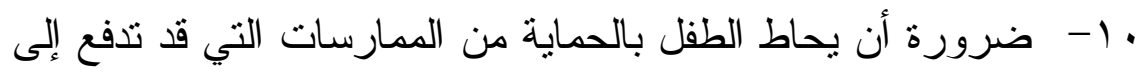

$$
\text { أي شكل من أثنكال التمييز. }
$$

\section{د-العهل الدولي الخاص بالحقوق المدنية والسياسية :}

" اعتمد العهد الدولي الخاص بالحقوق المدنية والسياسية وكنلك العهد

الخاص بالحقوق الاقتصادية و الاجتماعية، بقرار من الجمعية العامة في 17

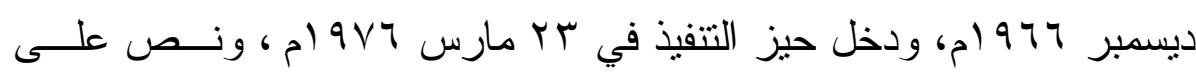

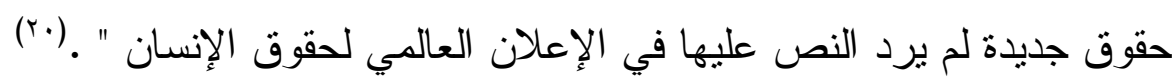

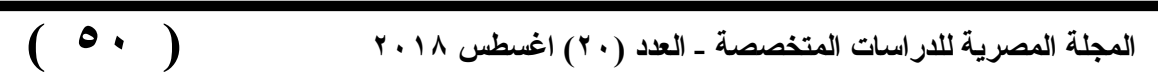




\section{حقوق الطقل فى مسرح "سمير عبد الباقى"}

كذلك أكد على " الضمانات التي من شأنها حمايــة حقــوق الطفــل

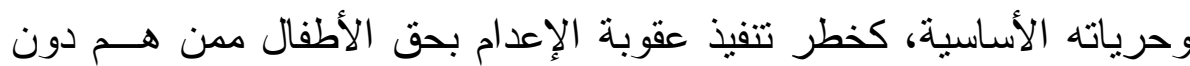

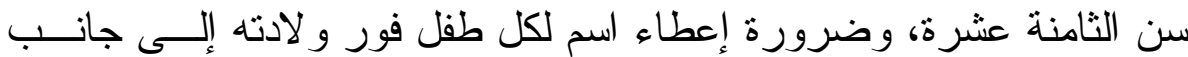

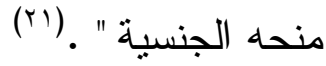

\section{هـ-العهل الدولي الخاص بالحقوق الاقتصادية والاجتماعية :}

" كفل العهذ حق جميع الأثخاص بمن فيهم الأطفال في التمتع بأفضل

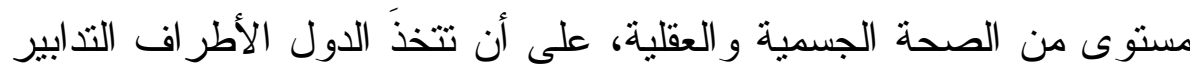

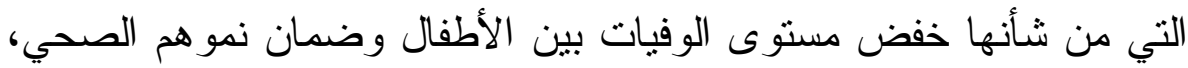

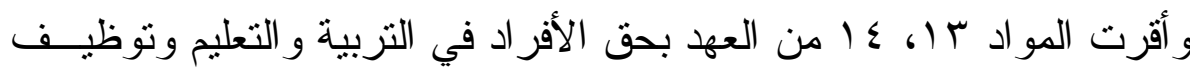

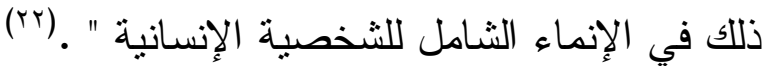

\section{و -|تفاقية حقوق الطقل عام 1919 :}

كانت أهم الحقوق التي منحتها الاتفاقية ونصت عليها لصالح الأطفال (rr) : هى

1- حق الطفل في أن يكون له أسرة. r- بق الطفل في الرعاية الصحية. r- ب عق الطفل في التعليم. ع - حق الطفل في أن يكون له اسم وجنسية. 0- حق الطفل في حرية العقيدة و الدين. צ- حق الطفل في حرية التعبير عن رأيه. V- حق الطفل في اللعب و أوقات الفر اغ و الر احة. ^- حق الطفل في الحصول على المعلومات المناسبة. 
وأُمحر (السير بحمر (السير

9- حق الطفل في المشاركة.

المحور الثانى : مسرح الطقـلـل .

أولاً : مفهوم مسرح الطقل :

يُعتبر مسرح الطفل " عرض مسرحى موجه إلى فئة مسن الأطفــال

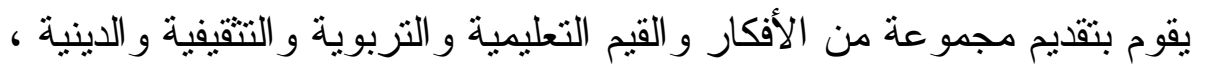

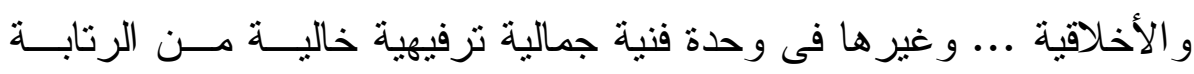

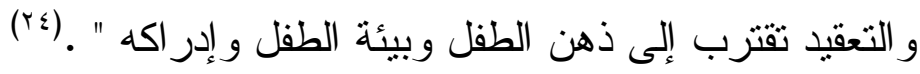

ويُعد أيضاً " الفن التثنيلى الذى يقوم على تقصص الثخصيات ، و أداء

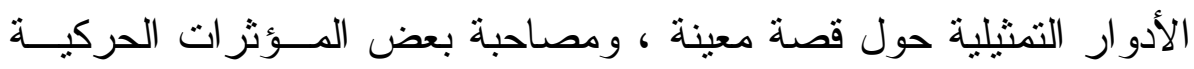

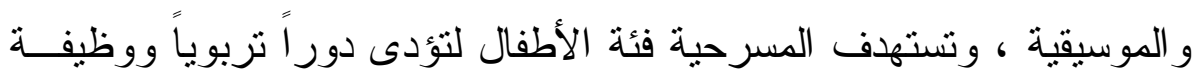

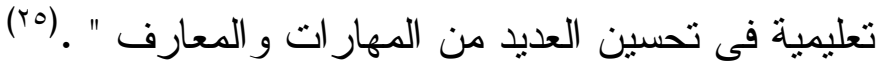

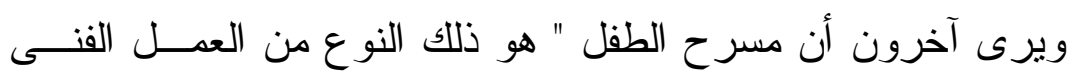

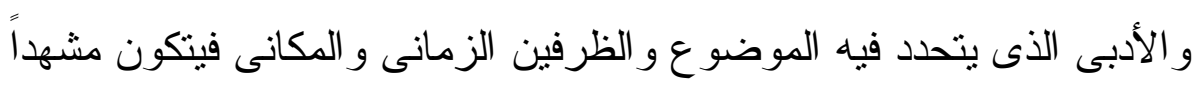

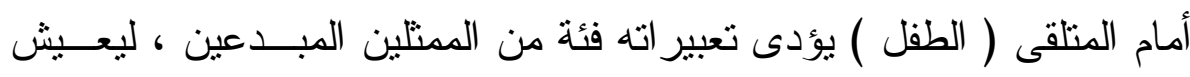

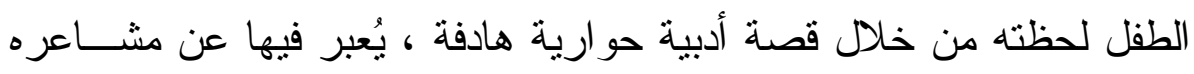

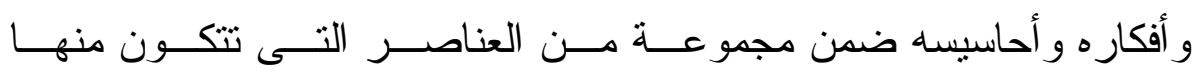

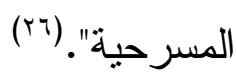

ويقدم المعجم المسرحى تعريفاً شاملاً موجزاً لمسرح الطفل ، حيــث

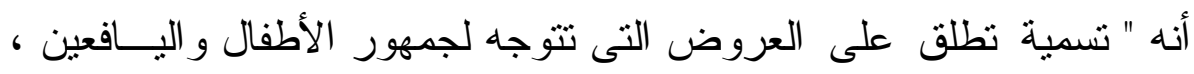

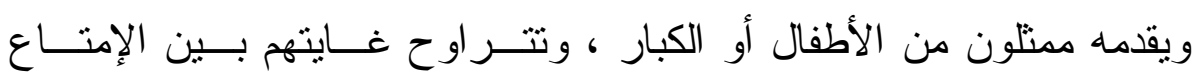

و التعليم". (rV)

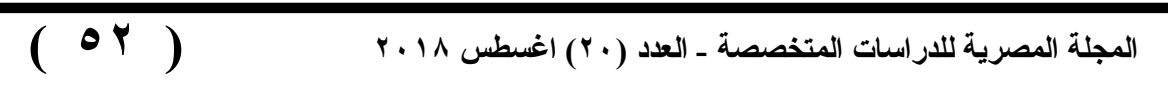


ويرى الباحث من خلال التعريفات السابقة لمسرح الطفل أنها اتفقت

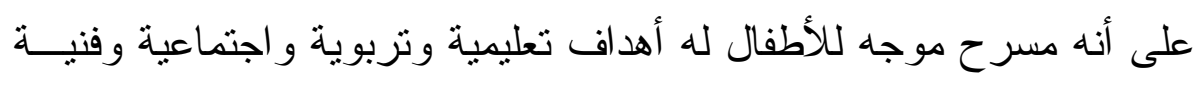

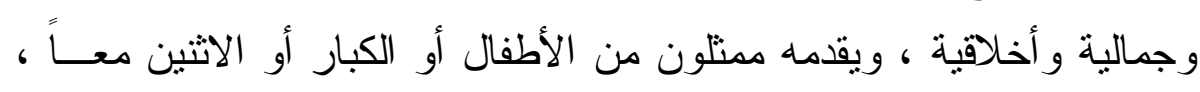

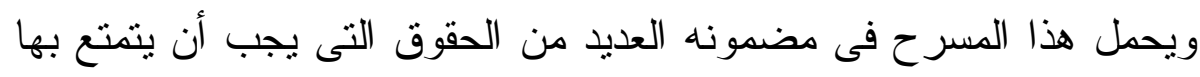

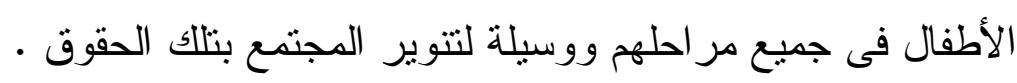
ثانياً : نشأة وتطور مسرح الطفل فى مصر :

" كانت النشأة الأولى لمسرح الأطفال فى مصر فى رحاب الددرسة

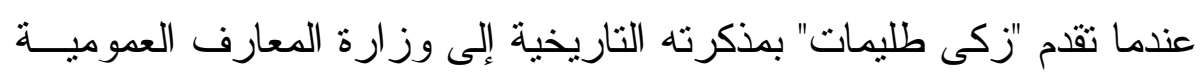

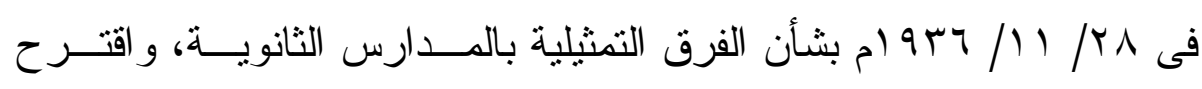

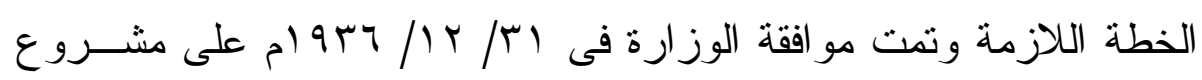

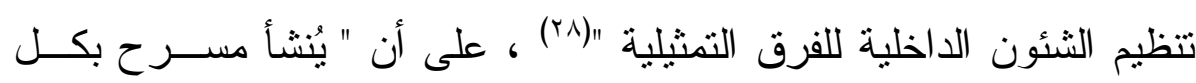

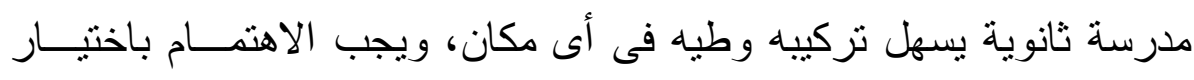

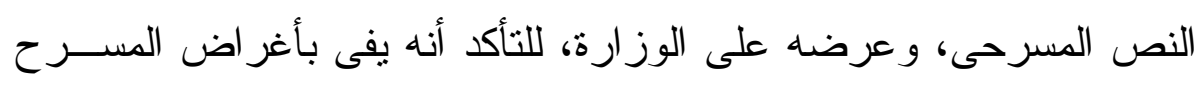

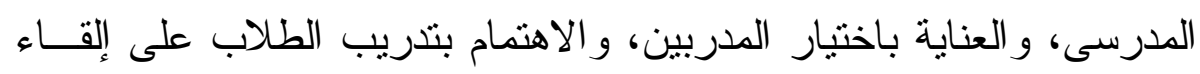

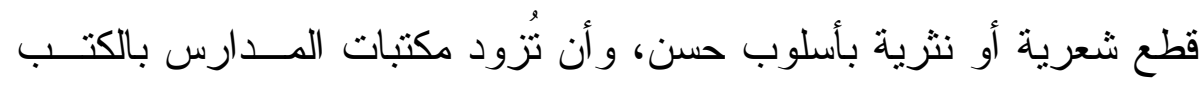

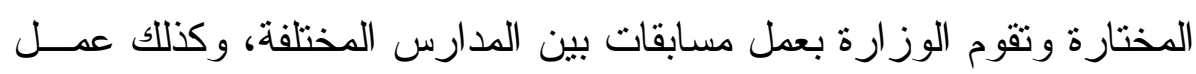

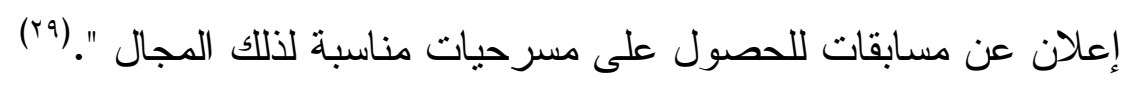
ويمكن القول أن أول محاولة جادة لإنشاء مسرح الأطفال فى مصر

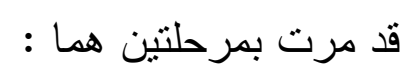

المرحلة الأولى : " قد بدأت فى يوليو سنة ؛ 97 ام عندما أنثــأت

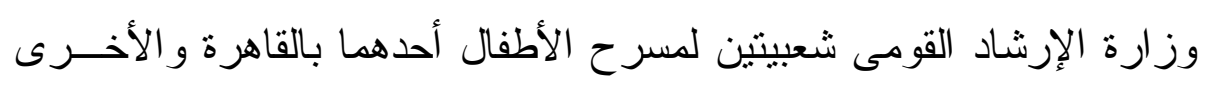

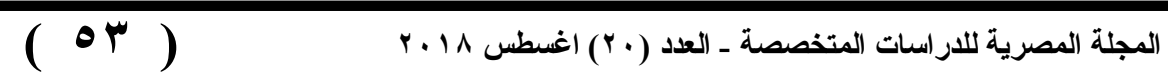


بالإسكندرية تبنته هيئة الإذاعة و التليفزيون وقد قدم مسرحيات عديدة منهــا المترجم و المقتبس و المؤلف ثم توقف فى عام 97 ام و و 971 1، ثم عاد فـى فبر اير سنة 979 ا تحت إثر اف وزارة الثقافة، وقد بدأ مسرح الطفل بتقديم مسرحية "مغامر ات سائح" التى قدمت فى الإسكندرية خلال أعياد الثورة فى الثى يوليو سنة ؟79 19 ، وفى أغسطس عام £ 197 تم تقديم العمل الثانى لمسرح الأطفال بالإسكندرية وقدمه الأطفال وهو مسرحية " قمة النصر " ، ثم انتقـلـل

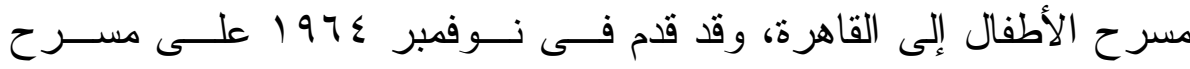
الهوسابير مسرحية " الحذاء الأحمر" ، وتعتبر هــذه المســرحية أول عمـلـ أهـ

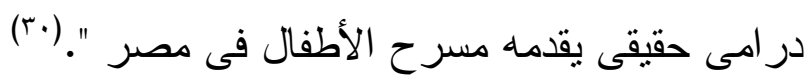
المرحلة الثانية : بدأت التجربة الثانية فى عام بV9 1، وكانت هذه المرة تحت إثر اف الثقافة الجماهيرية ، فقى مركز ثقافة الطفل بالقاهرة تـــ

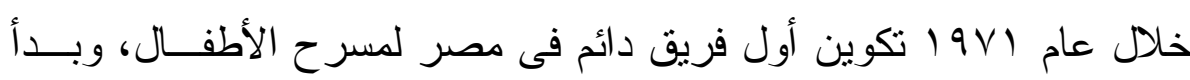
نشاطه بمسرحية "ساحر الذهب". (اיז) "وبعدها حضر إلى القاهرة مدير مسرح الأطفال فى برلين وأخرج مسرحية "الغابة المسحورة" ثم تو الت المسرحيات و العروض بصفة مســتمرة حيث قدمت مسرحية "سندريلا" ترجمة يعقوب الثـارونى و إعـــداد و إخــر اج فاطمة المعدول، ومسرحية "تيك العجيب" و "الجميلة النائمة" و "الولا الكسان"

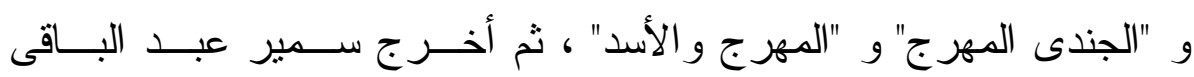
مسرحيتين هما "حسن قرن الفول" ومسرحية "مغامرة فى مملكة القرود"، وقد قدمت فرق الأقاليم المسرحية معظم هذه المسرحيات على مســار ح قصــور

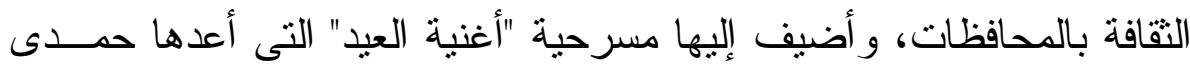


عباس عن رواية "لنتارلز ديكنز" و عدد من مسرحيات الفصل الواحـــــن تأليف يعقوب الثارونى ".(rr)

وفى عام الو ام قرر " أحمد زكى " عندما تولى رئاسة الهيئة وهو

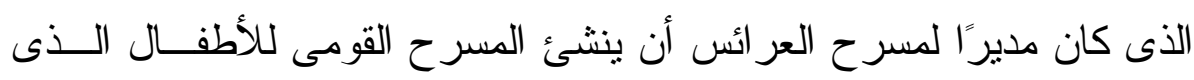

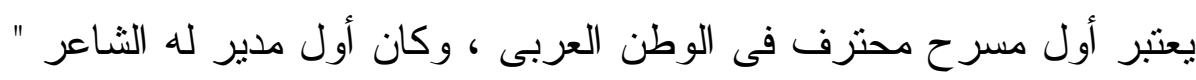
شوقى خميس "، ولم تقتصر عروض المسرح القومى للأطفال على القاهرة ، بل تجول فى كل أرجاء مصر ، و أقام دور ات تدريبية ، و أثنرف على لفى إنثــاء

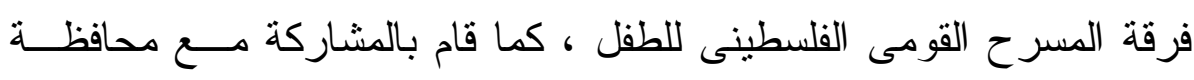

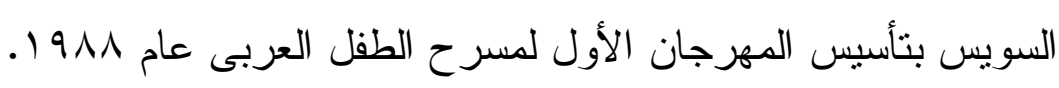

\section{ثالثاً : أهمية ووظائف مسرح الطفل :}

" يُعتبر مسرح الطفل وسيلة فعالة للأطفال حيث يستقيدون إلى درجة معقولة مما يشاهدونه فى المسرح سواء فى الاستجابة الوجدانية المباثرة وفقًا

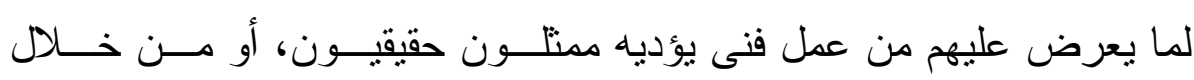

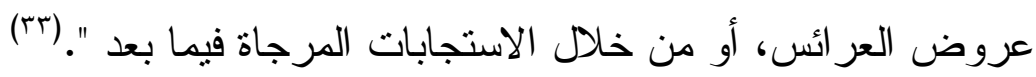

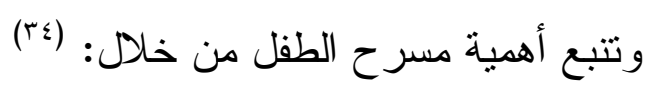

1- اكتساب الطفل لأنماط سلوكية جديدة ، أو على الأقل يعهـل علـى

$$
\text { تعديل بعض السلوكيات لديه. }
$$

r- تطوير المعارف و المعلومات بما يتلاعم و المر احل العمرية .

$$
\text { r- اكتساب مفردات لغوية جديدة . }
$$

ع - اكتساب نظام نقافى من القو اعد و القيم التى تتظم العمل الجمعى . 
وا أمحر (السير لحمر (السير

0- اكتساب بعض المهار ات الخاصة بالتفاعل الاجتماعى وخاصة القدرة

على ممارسة الدور الاجتماعى •

وبذلك " يُعد المسرح وسيلة فعالة لتتمية الطفل فـى عـدة جوانسب

و إكسابه العديد من المهار ات و القدرات " (ro) سواء الاجتماعية أو السـلـوكية

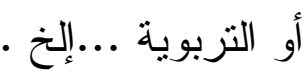

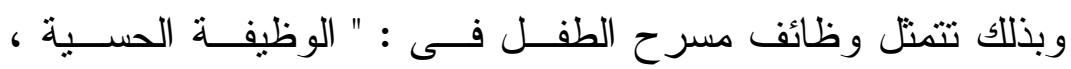

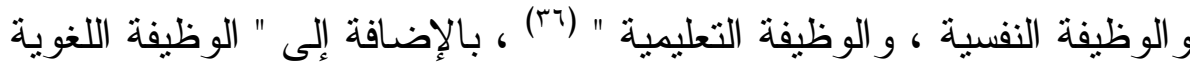

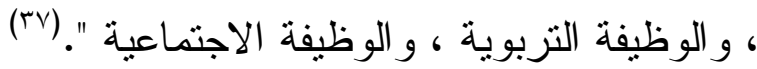

رابعاً : أهداف مسرح الطفل :

تتمثل أبرز الأهداف التى يمكن أن تتحقق من خــلد المسـرحيات

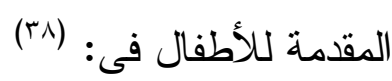

1- إثارة انبهار الطفل و الثرفيه عنه .

r- إكساب وتتمية القيم الخلقية و الحسية للطفل .

ب- تتمية قدرة الطفل على الملاحظة و الانتباه .

ع - تقديم مادة ثرية للطفل فى الأدب و الموسيقى وفنون الحركة و التشكيل.

0- تزويد الطفل مهار ات وخبرات جديدة .

1- تفريغ شحنات الأطفال الانفعالية .

V- وسيلة لإثارة اهتمام الأطفال بالعلوم •

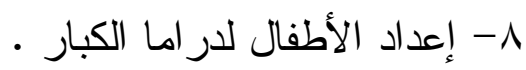

9- 9تمية التفكير الابتكارى .

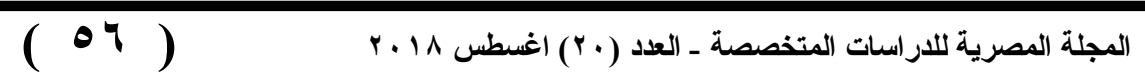




\section{حقوق الطفل فى مسرح "سمير عبد الباقى"}

ويمكن تلخيص تلاكك الأهداف من خلال الثأثثر الإيجـابى لمســارح

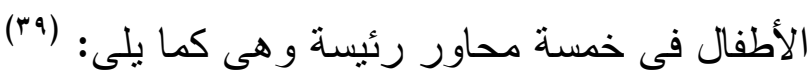

1- غرس القيم النبيلة وتقيم القدوة الحقيقية .

r- تزويد الأطفال و النشء بالمعلومات و الخبرات الجديدة .

r- تتمية الإحساس بالجمال و التنريب على التذوق الفنى السليم .

ع - التّريب على عادة الذهاب إلى المسرح و الالتز ام بتقاليد الششــاهدة

$$
\text { المسرحية . }
$$

0- اكتثاف الو اهب فى مختلف المجالات وتتميتها .

الار اسة التحليلية ونتائجها:

$$
\text { 1- مسرحية " أحلام سقا " : }
$$

يؤكد " سمير عبد الباقى " على العديد من حقوق الطفل فى مسرحية

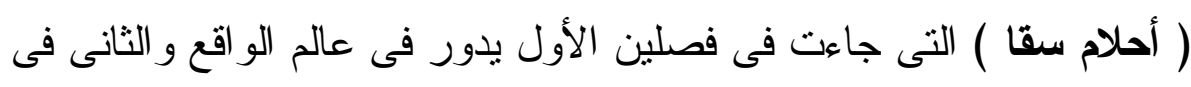
عالم الخيال ، ومن تلك الحقوق الحق فى اللعب و التزفيه الذى يُعدُّ متتفساً للطفل " فاللعب نشاط عفوى يُمارس بهدف المتعة وهو من خلال الرمزية

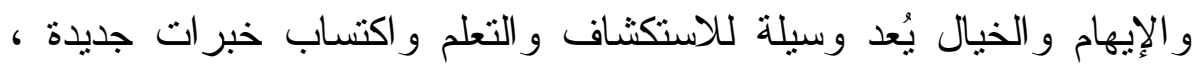
وللعب وظيفة اجتماعية ونفسية يساعد الطفل على تتمية قدر اته فى التعلم ولماله

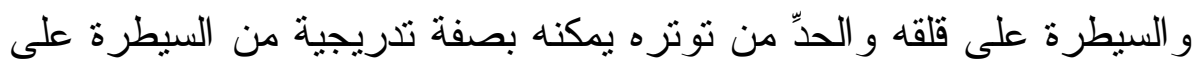

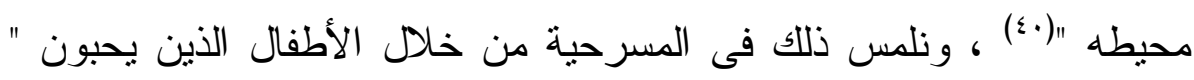

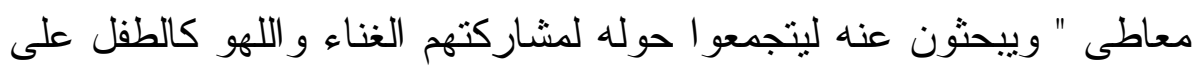

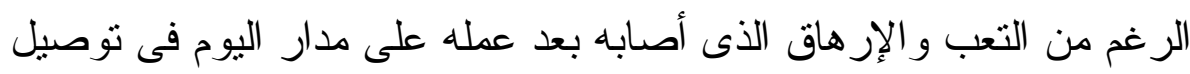

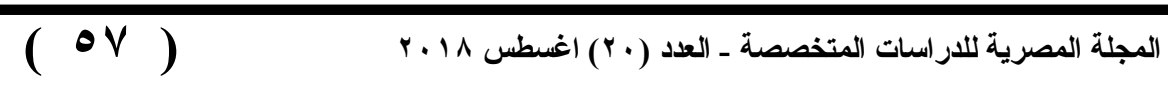


وا أُمر السير ححمر السير

المياه لأهالى القرية ، وكنلك خوفه من زوجته " مرزوقة " التى توبخه

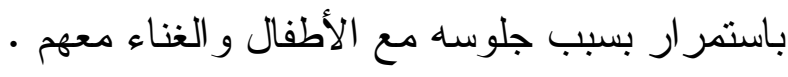

الأطفال : هيه هيه اللى حيجى فله عليه .

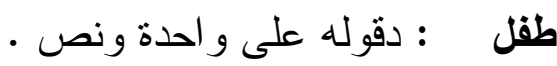
معاطى : وأنا راح أغنى وأقول وأرص وله .. دأهل دأنا وياكم زدت النص .. ومعاكم بتخف حمولى .. دقولى أه دقولى دقولى على على واحدة

ونص. (1)

كذللك تتاول " سمير عبد الباقى " الحق فى التعليم فى مسرحية (أحلام

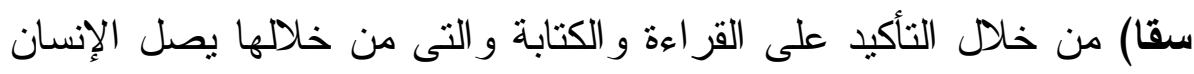

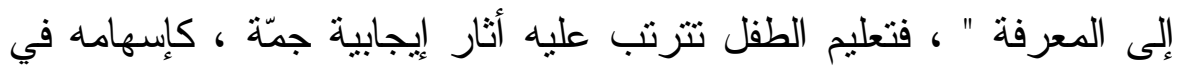
تتمية قدر اته وشخصيته وفي حمايته من كثير من الانحر افات و المخاطر التي

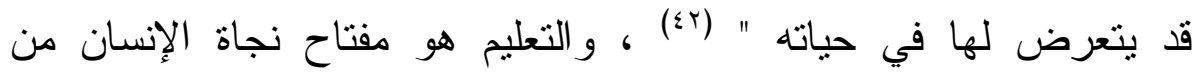

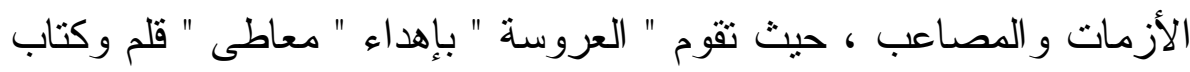

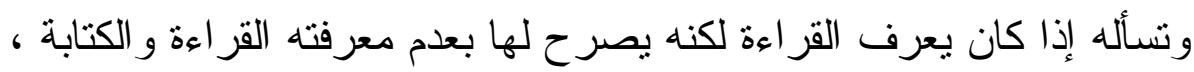

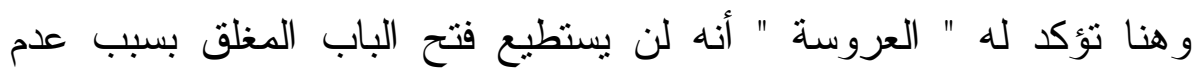

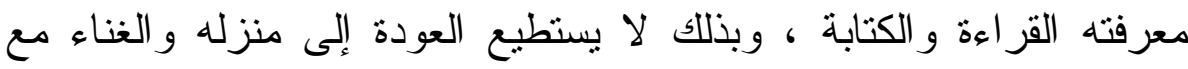

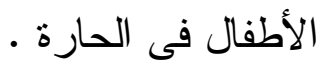

معاطى : : و النبى يا عروسة تقوليلى فين الأو لاد ؟ العروسة : تعرف تقر أ ؟ : معاطي

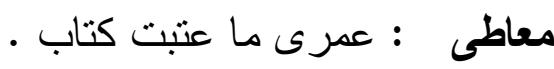

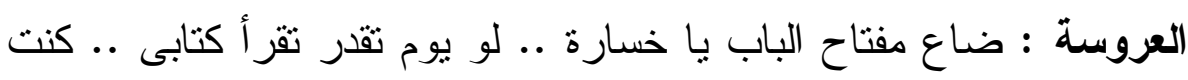

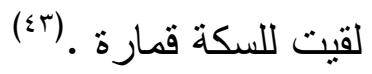

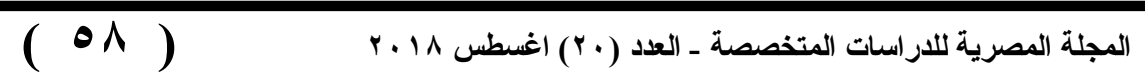




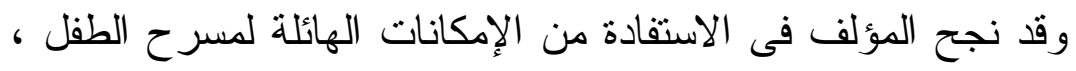

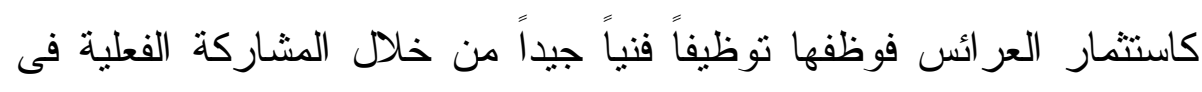

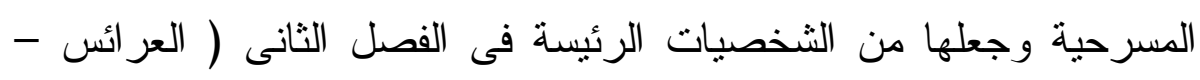

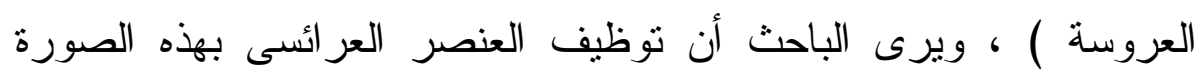

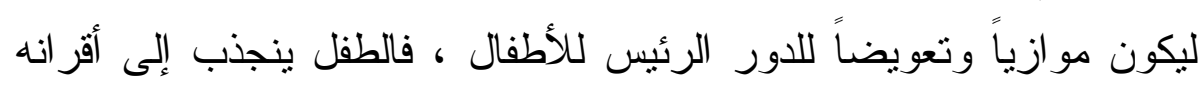

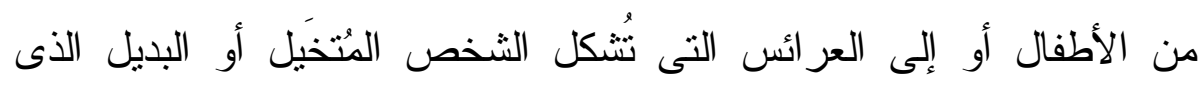

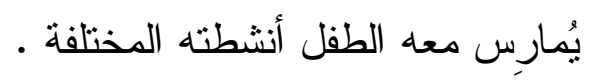

ويؤكد المؤلف - فى نهاية المسرحية - على الحق فى التعليم ؛ حيث

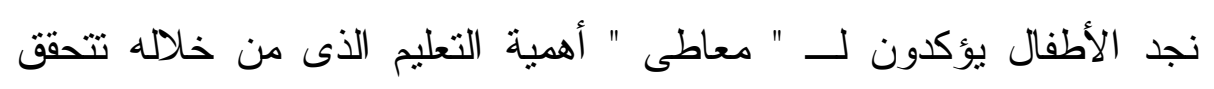

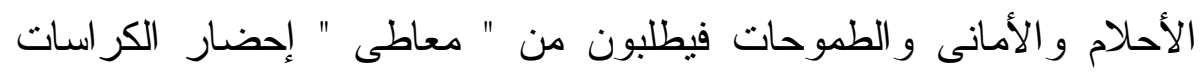
و الأقلام ليتعلم الحروف و القر اءة و الكتابة ، وهنا يُيرز المؤلف ولفئ وعى الأطفال بحقهم فى التعليم الذى ينير لهم الطريق نحو المستقبل . معاطى : الأولاد زى العصافير .. عايزه تريش لجل تطير •

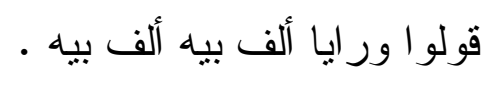

الأولاد : يا سقا طوح كمك..ايدنا فى ايدك ما يهمك..

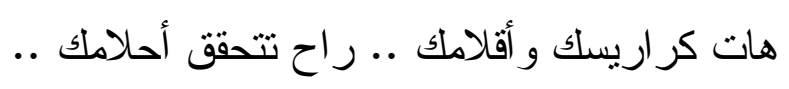

جنتا احنا حنعملها .. و الحدوته احنا نكملها..

$$
\text { ألف بيه .. ألف بيه . (๕) }
$$

ويرى الباحث أن المؤلف نجح فى إثرالك الأطفال فى مسرحيته ،

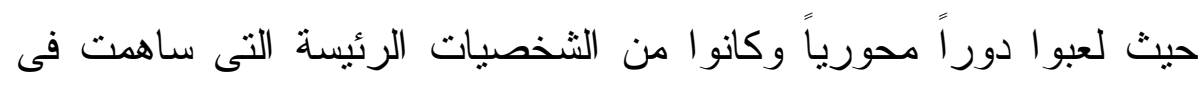

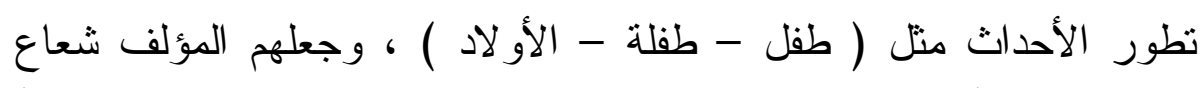

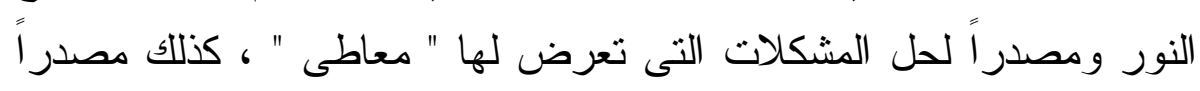

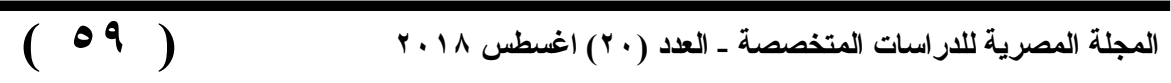


وا أمحر (السير لحمر (السير

للابهة و الفرح و السرور من خلال أغانيهم ورقصهم ، معبر اً من من خلالهم على حقوق الطفل المختلفة .

$$
\text { r- مسرحية " أرنب فوق العادة " : }
$$

نسج المؤلف مسرحيته فى عالم الحيوان من خلال مجموعة حيو انات

تعيش فى الغابة ( الأرنب - القرد - الدب - الحمار - المعزة - البقرة ) ) ل وهى حيوانات يحبها الأطفال ويتفاعلون معها من خلال لغة نثرية فكاهية تتخللها بعض الأتشعار فى المشاهد الغنائية و التى وظفها المؤلف فى تقديم كل

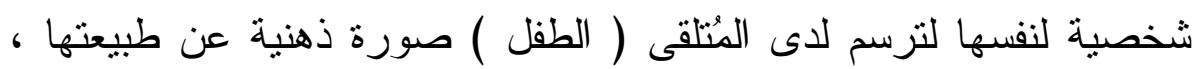

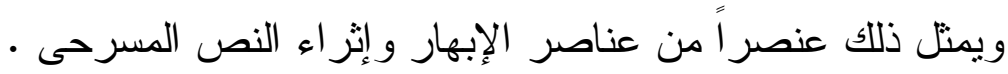
تدور الفكرة الرئيسة فى مسرحية ( أرنب فوق العادة ) حول الحق

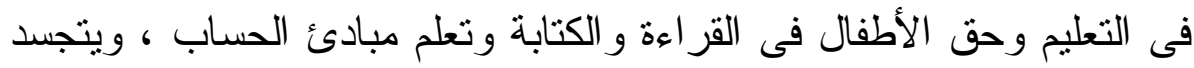
ذللك من خلا " الأرنب " الذى يبدأ فى الغناء منذ البداية أغنية الأرنب المتعلم التى يؤكد من خلالها معرفته القراءة والكتابة وقدرته على معرفة الأرقام ومبادئ الحساب وأن ذلك حق من حقوقه الأصيلة . الأرنب : أنا أرنب وبقيت أرنوب .. وعرفت أقرأ اللى مكتوب .. أقدر أكتب اسمى و احسب .. و احد اثثين يا حساب محسوب . أصل العلم دا بحره غويط .. و عثان عقلى كبير وخويط ..

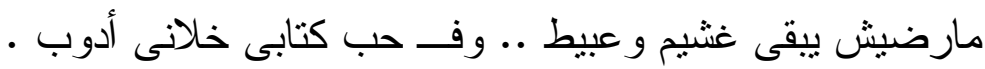

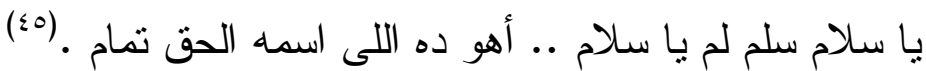
وبينما " الأرنب " يغنى يقاطعه " القرد " ويسأله عن سبب فرحته وغناءه فيشير "الأرنب" إلى الكتاب الذى يحمله و أنه أرنب متعلم يسنطيع

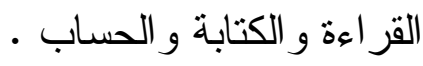

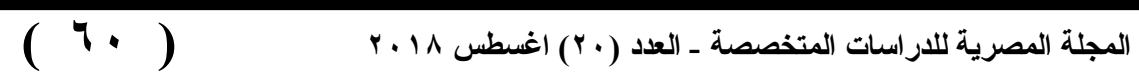


الأرنب : ده كتاب .. فهمت ؟ .

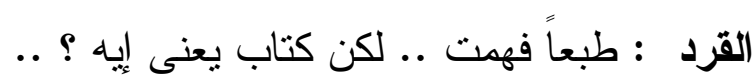
الأرنب : يعنى ورق مكتوب فيه كتابة حروف وكلام و علوم وفنون .. و وأما

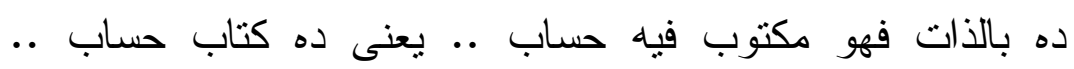

$$
\text { فهمت. دَ) بالات }
$$

ويستمر " الأرنب " فى التأكيد على الحق فى التعليم لباقى الحيوانات

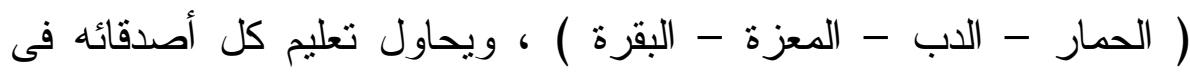
المزرعة القر اءة والكتابة والحساب ، ولكنهم ينصرفون عن ذلك رغم تأكيده

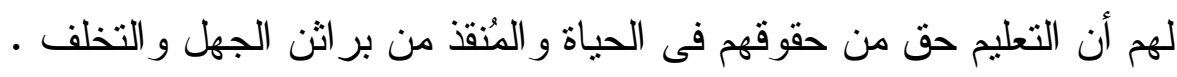
الأرنب : يا عم حمار .. الحكاية إنى أنا بتعلم فى الددرسة ، علثان أعمل

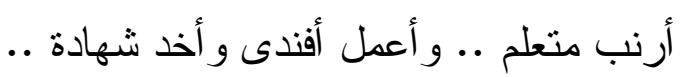

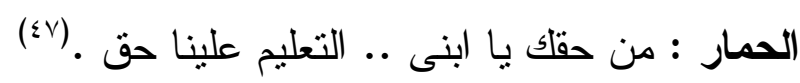
وعندما تقع الحيوانات فريسة للصيادين الذين يجهلون بالقراءة

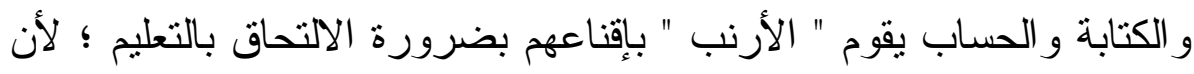

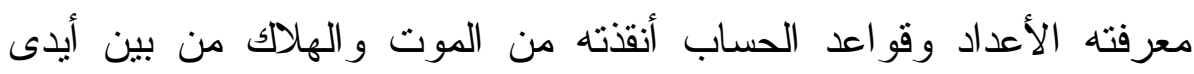

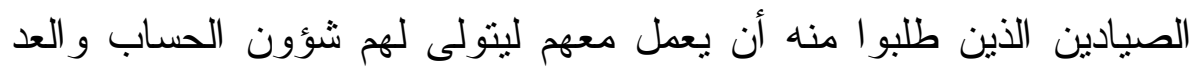

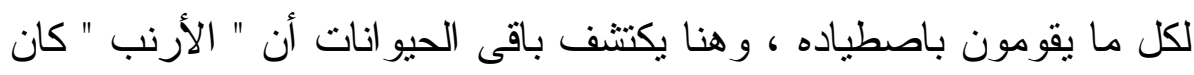

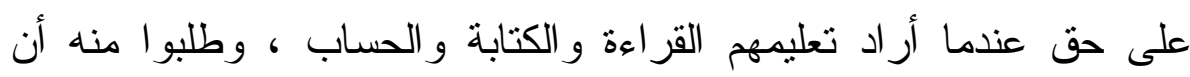

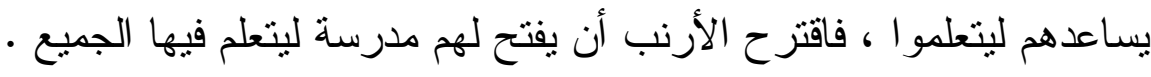
الصيادين : عندك حق .. لكن نعمل إيه ؟.. عندك حل يا أرنب أفندى ..

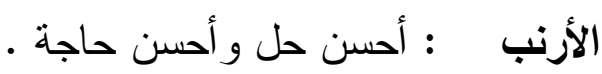


وا أمحر (السير لحمر (السير

$$
\begin{aligned}
& \text { أفتحلكم مدرسة مشتركة . } \\
& \text { و أنا متأكد إنى عقولكم . } \\
& \text { حيطر ح فيها الخير و البركة . }
\end{aligned}
$$

وفى إطار مغلف بالكوميديا يطرح المؤلف أحد حقوق الطفل و التى حرص عليها الإسلام وهو حق الطفل فى اختيار الم مناسب ، حيث " إن

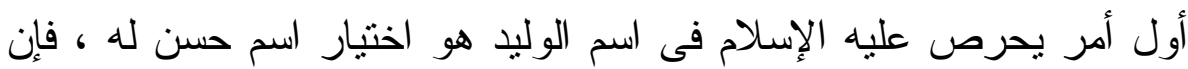
للاسم نأثيراً على شخصية صاحبه ونفسيته ، فإن كان اسماً وحشياً وغليظاً

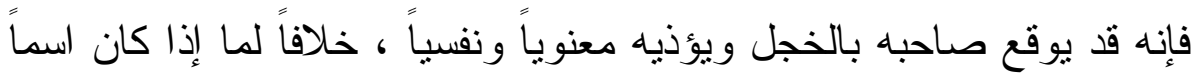

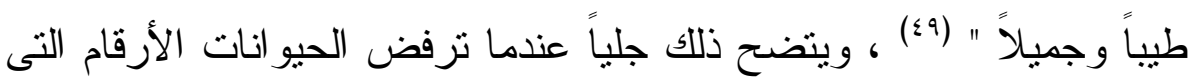

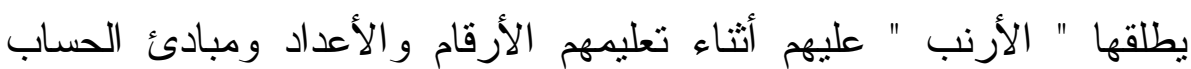

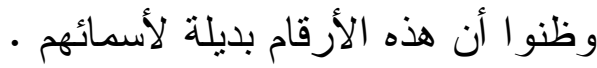
البقرة : ح يقول للك يرصنا ويعدنا .. وبعدين يغير إسمنا ..

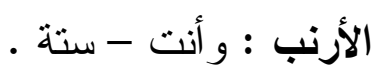
الاب : كمان .. يعنى حتى الاسم ده مستكتره عليه .. (ستة) أنا ح أستت

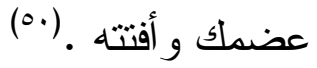

\section{r- مسرحية " قرص عسل من غير كسل " :}

تدور المسرحية فى مشهدين داخل مزرعة يعيش فيها " النحل " رمز

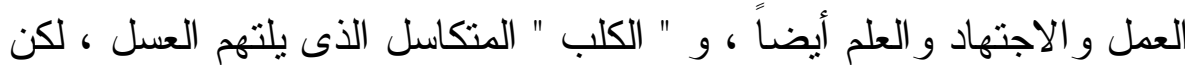

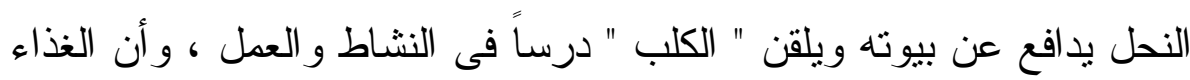
حق لمن يعمل فقط .

تتاول " سمير عبد الباقى " الحق فى الحماية فى مسرحية ( قرص عسل من غير كسل) ، " ويشمل حق الطفل فى الحماية حمايته من كل فعل فئل

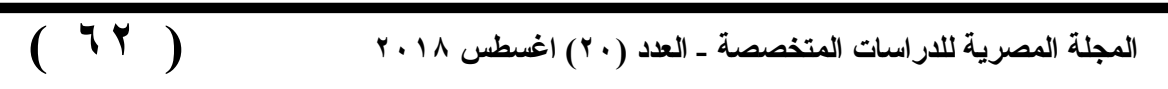


متعمد أو غير متعمد يقع على الطفل يؤدى إلى إصابته بالأذى سواء كان هذا

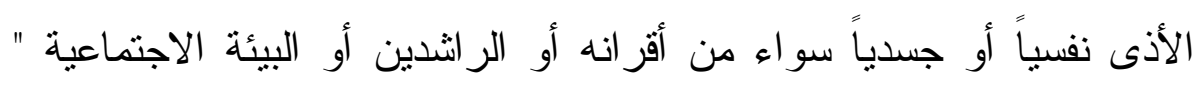

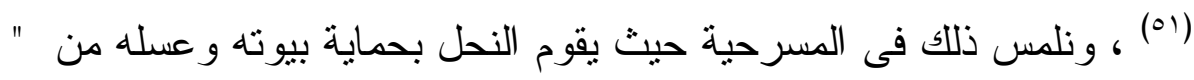

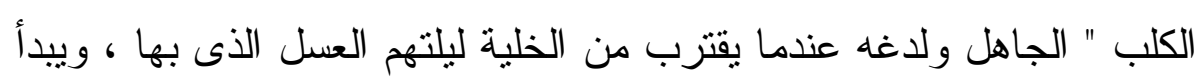

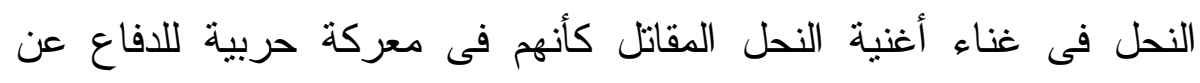

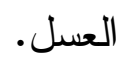

النحلات : للقتال هيا .. نحمى حمى الخلية .. أصل الخلية .. هيه بيتتا وبيت

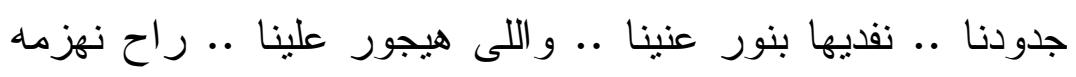

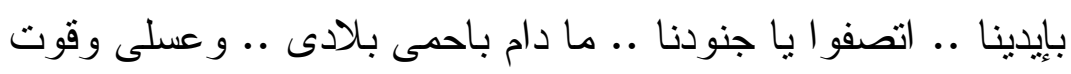

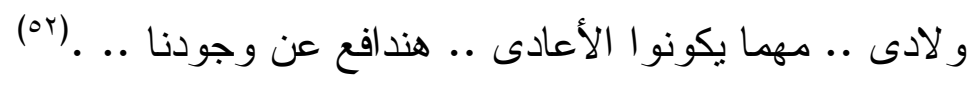

ويقرر " الكلب " فى النهاية الدفاع عن النحل وحمايتهم من الفئران مقابل حصوله على العسل . الملكة : حقاك عسل على شغلتك . الكلب : يا سلام خلاص .. أنا ح أثنتغل .. .

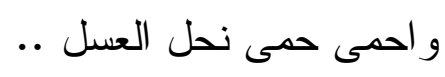

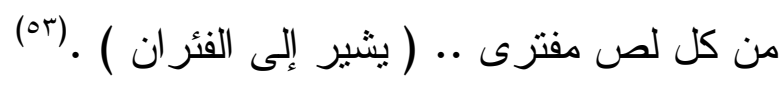

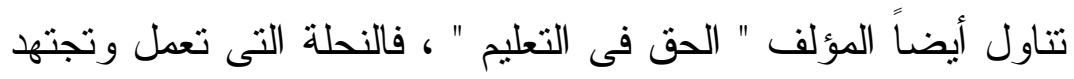

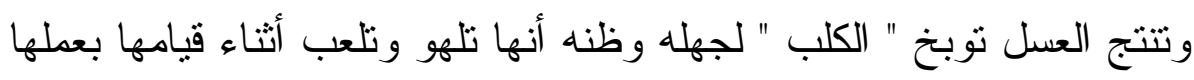

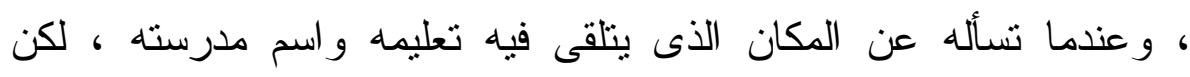

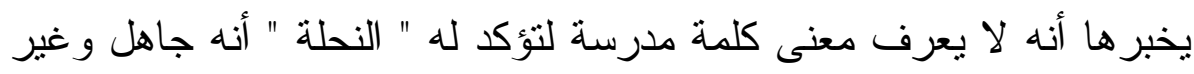

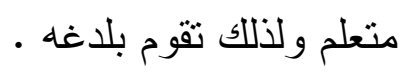


النحلة : لسه فاكرنى بالعب .. يا جاهل ؟ أنت بتتعلم فين ؟...وفى أى مدرسة

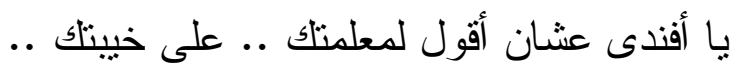

$$
\text { الكلب : مدرسة ؟ .. مدرسة يعنى إيه ؟... }
$$

النحلة : يا خبر .. كمان مش عارف يعنى إيه مدرسة ؟... لا .. دا أنت

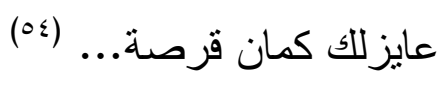

كما أكد المؤلف أيضاً على الحق فى الغذاء كأحد الحقوق الأساسية

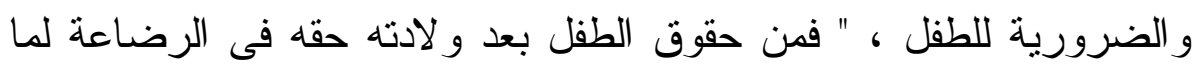

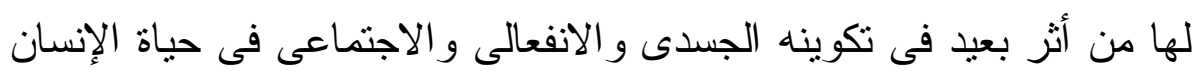

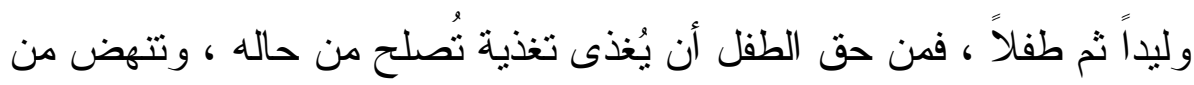

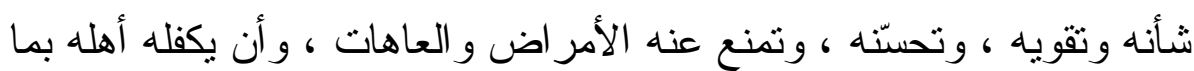
يناسبه ". (00)

ويتجلى الحق فى الغذاء فى المسرحية عندما يطلب " الكلب " من

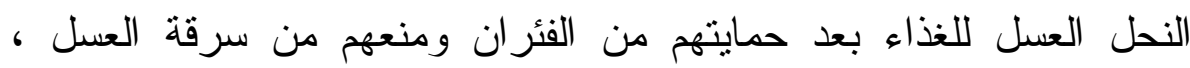

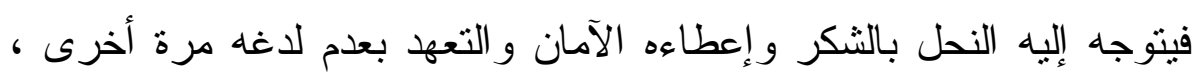

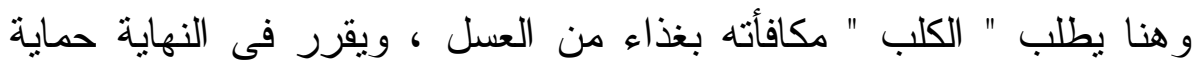
النحل من الأعداء مقابل حصوله على الغذاء . الكلب : لكن ما دام فينا الأمان .. هاتو ا العسل قو ام بقى ..

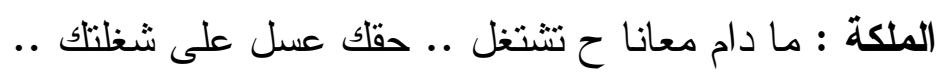

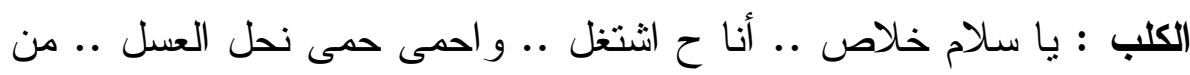

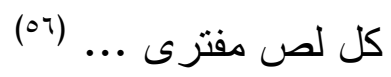
وقد وظف المؤلف شخصية " الر اوى " الذى اضطلع بدور محورى ، الرى فى المسرحية ، فهو الذى يقوم بالحكى أو السرد ، ويوجه الأحداث 


\section{حقوق الطقل فى مسرح "سمير عبد الباقى"}

ويختصرها وينهيها ، وكثيراً ينتخل لتبصير " الكلب " ونوجيهه ، و استخلاص العظة والحكمة التى طرحها فى بداية وختام المسرحية ، ويرى ولير

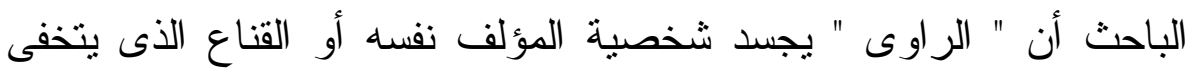
ور ائه من أجل غاية فنية أو تعليمية ، فنجده يتوجه للجمهور ويخاطبهم لييرر

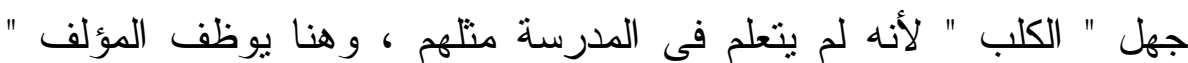
الر اوى " ليؤكد على الحق فى التعليم الذى به يصبر الإنسان و اعياً مستنبراً. الراوى : ( فى إمكانية حوار مع الجمهور ) معلش .. معذور .. أنا شخصياً

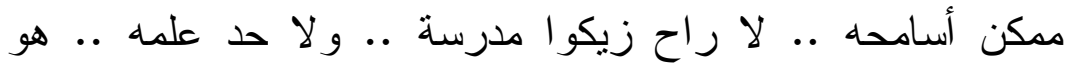

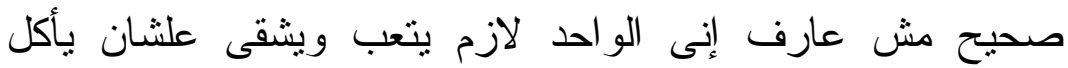
العسل .. لكن بالرغم من الكسل هو طيب وبكره ياما هيفهر

$$
\text { ويعرف. (ov) }
$$

\section{ع - مسرحية " كتكوت فصيح جداً " :}

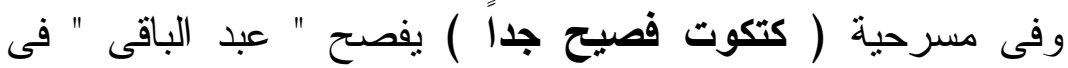

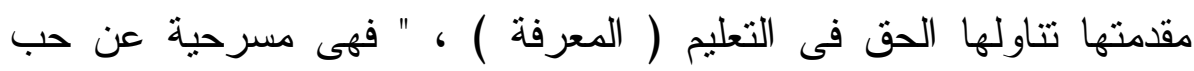

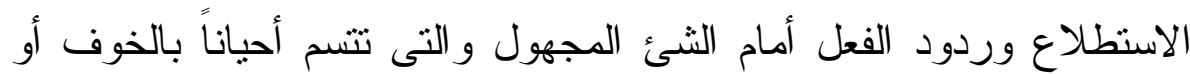
بإدعاء المعرفة أو التهور .. وفى كل الحالات بالحيرة الطفولية لقلة الخبرة

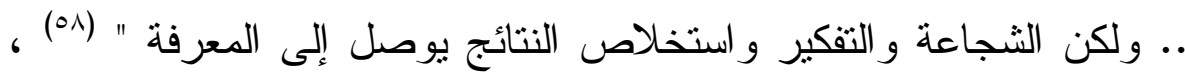

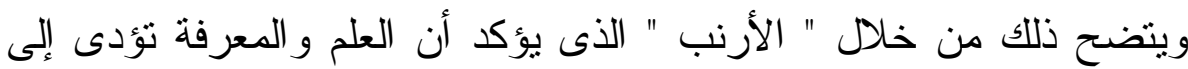

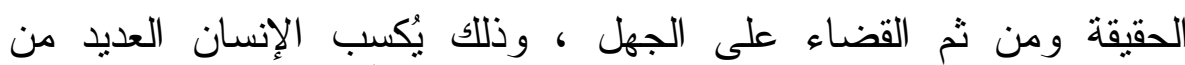
المهار ات الثخصية كالثجاعة و الثقة بالنفس ...إخخ . 
الأرنب : خايف ليه ؟ لماذا ؟ تشجع .. لو كان شيئًا ستعرف .. خايف من إيه

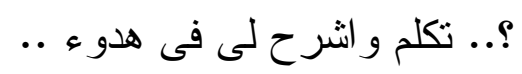

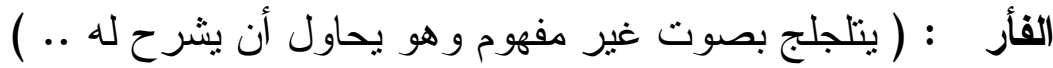
الأرنب : عادى إنك تخاف من شئ لا تعرفه لكن عندما تعرفه .. لن تخاف منه ... (09)

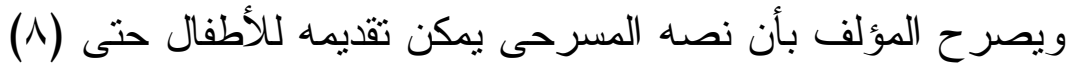

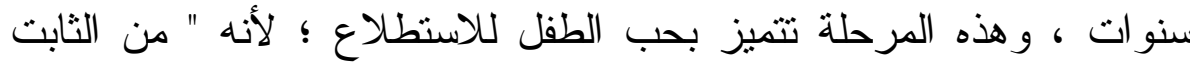

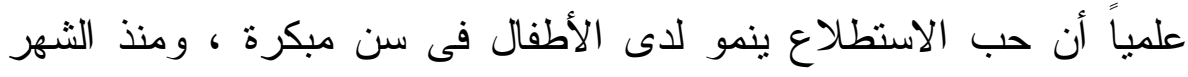

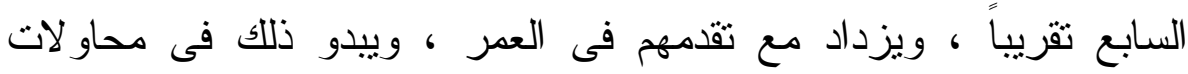

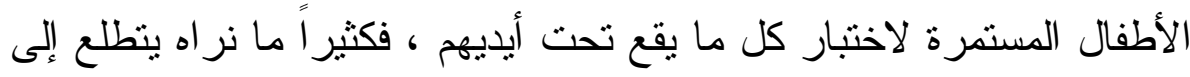

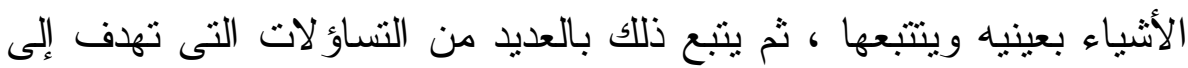

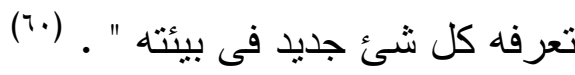

ويتجلى حب الاستطلاع من خلال جميع الحيو انات فى المزرعة التى تبحث عن سر الثئ العجيب الموجود داخل شئ أبيض ودائرى يهتز ويتحرك ، ويبدأ كلاً منهم فى طرح أسئلته وتخمين ما بداخل الثنئ المجهول.

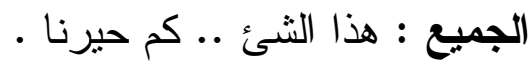

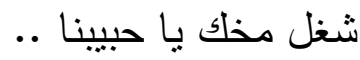
فهمنا وممنوع تتعبنا .. هيا إخبرنا .. قول يا حمارنا .. يا أكبرنا ـ (11)

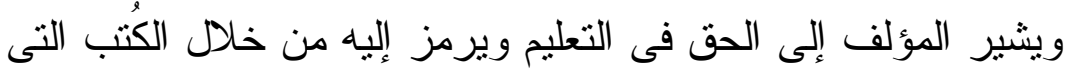
يحملها أحد الحيو انات ( الحمار ) ، حيث يؤكد " الأرنب " أن الكتب بها كل فئل 
شئ ومن خلالها يصل الإنسان إلى الحقيقة ويسنطيع حل جميع المشكلات

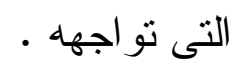

الأرنب : ها ..إنه يحمل كتباً .. بالتأكيد سيخبرنا حقيقة الموضوع ـ معه كتب . و الكتب بها كل شئ . الحمار : فرحانين لأنى جيت .. لو هناك مشكلة فأنا حلال المشاكل ... لو

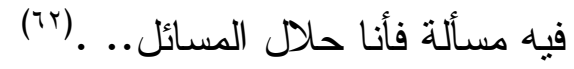

وقد وظف المؤلف الحوار توظيفاً فنياً يتو افق مع طبيعة المرحلة العمرية التى أثنار إليها فى بداية المسرحية ، فجاء الحوار باللغة العامية

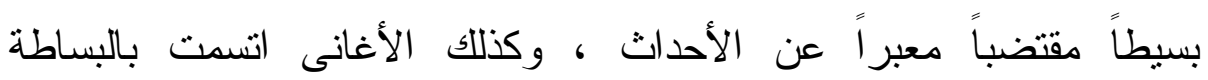
و الوضوح و القصر ، وكانت الثخصيات من الحيو انات الأليفة التى يأنس إليها

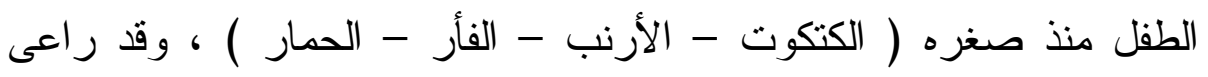
المؤلف عدم الإكثار من الثخصيات حتى لا يتشتت انتباه الطفل ، وبذللك نجح المؤلف فى توظيف كافة عناصره الفنية لتحقيق غرضه من خطابه المسرحى لأن لفي

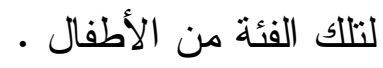

\section{ه- مسرحية ( سبع فى القفص أو اعمل معروف يا قرد ) :}

يثير " عبد الباقى " أن ( سبع فى القفص أو اعمل معروف يا قرد )

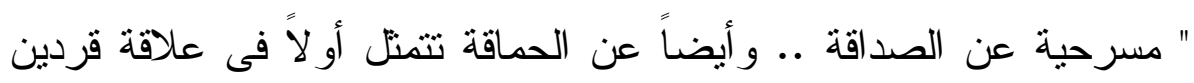

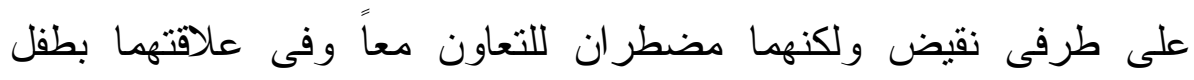

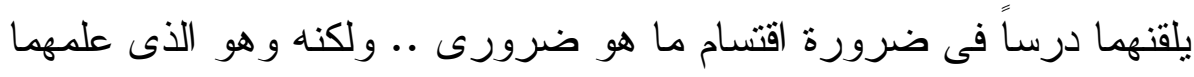

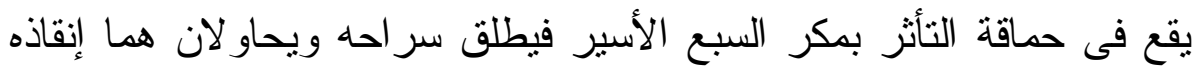

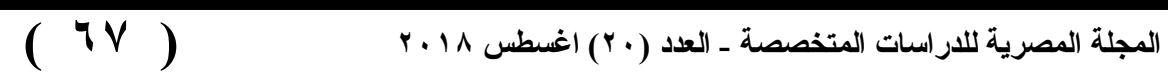


وا أُمر السير محمر السير

. . و أيضاً هى عن العقل الذى يجب أن يحمى صاحبه بالعودة إلى الصواب لهاب

ويجعله أقوى من ملك الغابة ". (Tr)

وتقع المسرحية فى فصلين باللغة العربية الفصحى ، لذلك أثنار

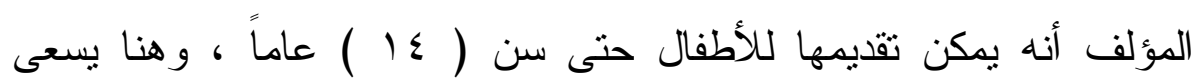

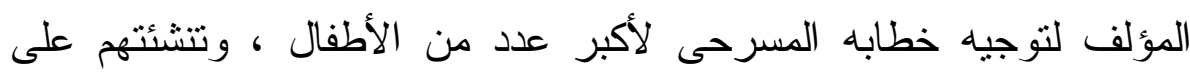

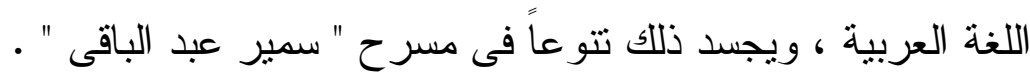

لقد وظف المؤلف شخصية الطفل كثخصية رئيسة لنصاه المسرحى

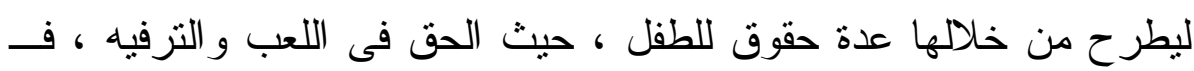

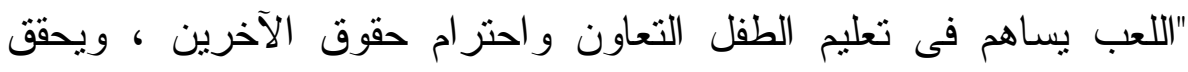

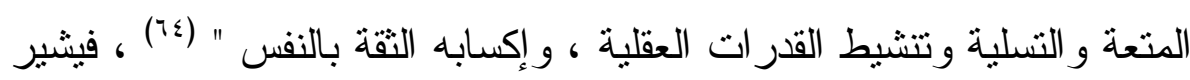
منذ البداية للطفل الذى يلعب فى الحديقة بالأشجار و الأغصان ويغنى ويشم - الأز هار

الطقل : ( الطفل سعيداً يغنى وهو يشتم الأزهار ويلعب بالأغصان .. )

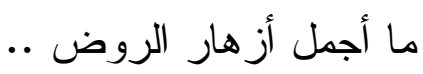

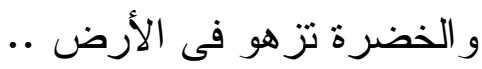
و الطير يغنى .. فرحاناً ... (70)

ويرى الباحث أن الثقة التى يتمتع بها الطفل جعلته يشعر بالحرية

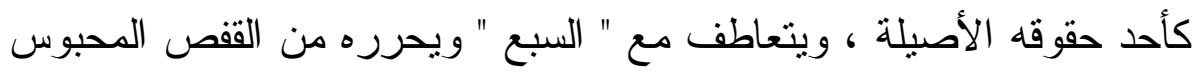

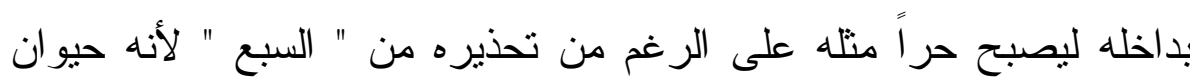

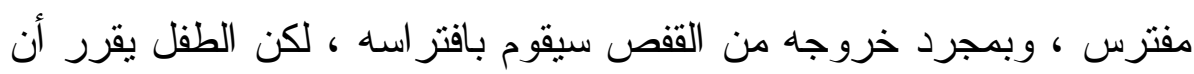

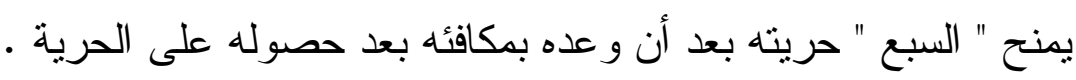
الطفل : أنا حر .. أغنى .. أو ..

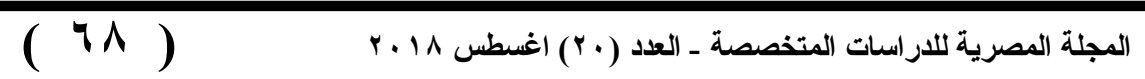




\section{حقوق الطقل فى مسرح "سمير عبد الباقى"}

السبع : لا أقصد .. أنت حر طبعاً .. غنى فأنت حر وسعيد ..

الطقل : ها ... ها أنت حر الآن .. ولم تعد محبوساً فى قفص .. بل عدت

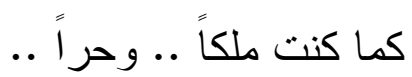

السبع : آه .. أنا و عدتك ... ولكن ألا ترى أن لى حق فى الإنتقام ؟..

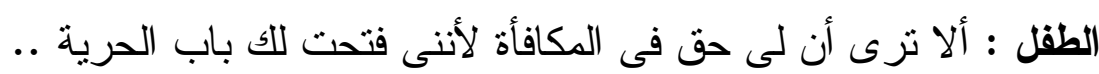

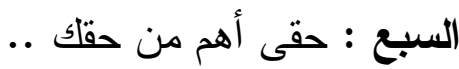

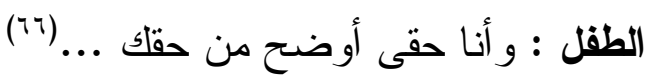

و أكد المؤلف على الحق فى الحماية ، حيث يسعى القردان لحماية "

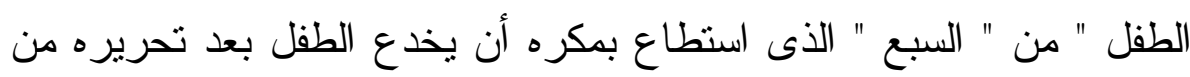
الققص الذى كان محبوساً فيه .

الطفل : لا تتعب نفسك أيها الغادر .. هذا القفل سيمنع السذج من أمثالى من

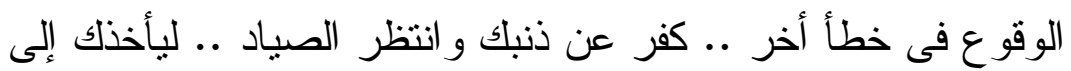

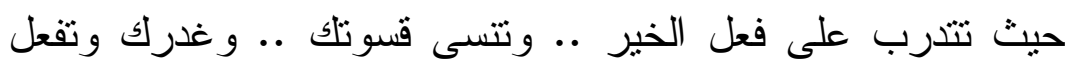

$$
\begin{aligned}
& \text { شيئًا يسعد الأطفال .. ألى أب ... . (TV) } \\
& \text { צ-مسرحية " الكوكب الرمادى " : }
\end{aligned}
$$

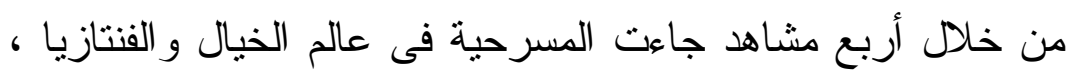
حيث الكوكب الرمادى الذى يناثد الجميع لإنقاذه من لونه الأوحد (الرمادى)،

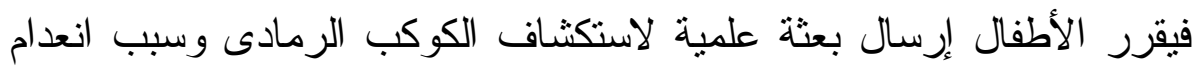

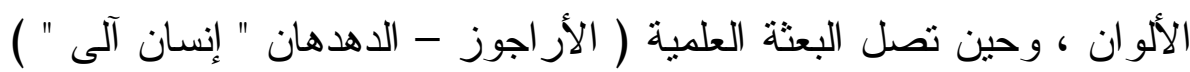

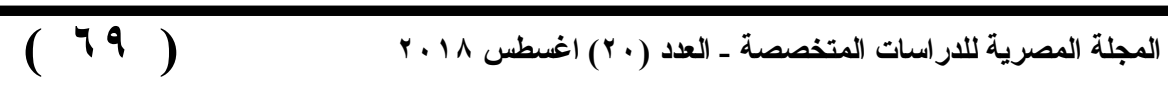


وأُمر (السير ححمر السير

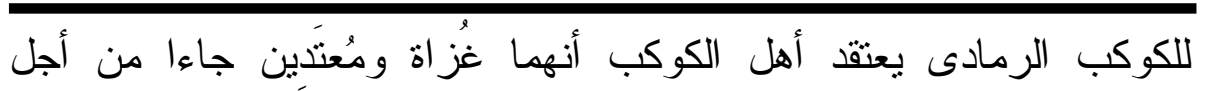

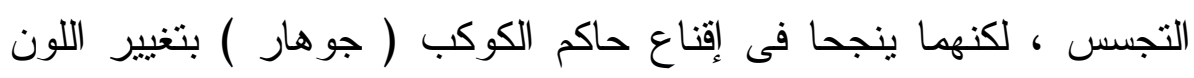

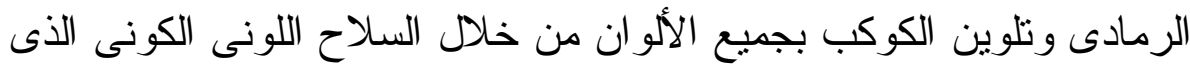

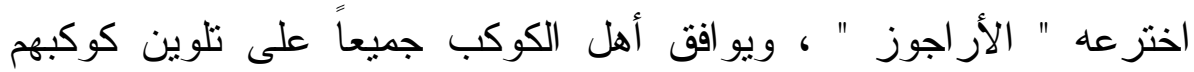

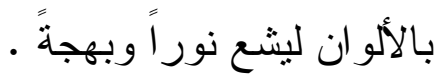

يؤكد " عبد الباقى " على الدق فى التعليم ( العلم ) ، فـ " الأراجوز

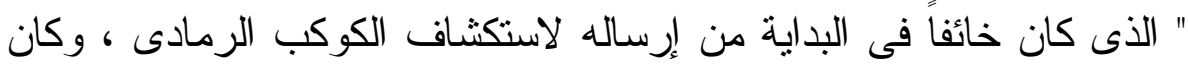

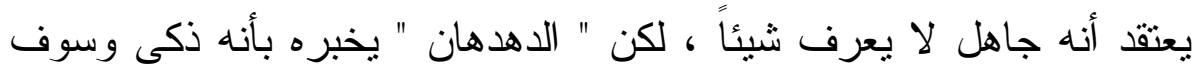

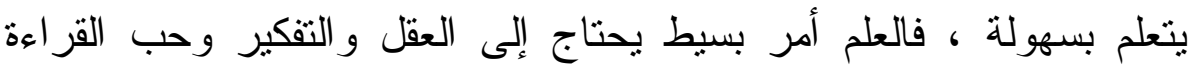

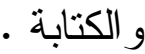

الاهدهان : هذا أمر بسيط .. أنت ذكى ستفهم بسرعة .. ليس هناك مستحيل

$$
\begin{aligned}
& \text { غنوة : تعب العلم ده أمر بسيط . } \\
& \text { نار ه لذيذة مبتحرقش . } \\
& \text { بص وحقق و لا نز هقشى . }
\end{aligned}
$$

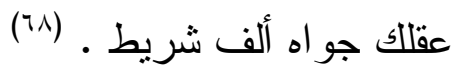

وقد اهتم المؤلف بتقديم العديد من المعلومات العلمية ، حيث ذكر على لسان شخصياته أهمية ضوء الثمس لتغذية النباتات من خلال مادة "

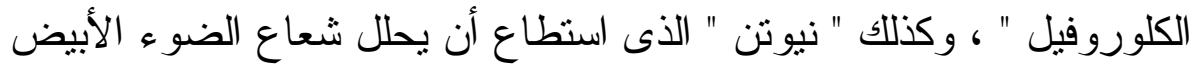
عن طريق جهاز قائم على أساس عدسة المنشور الزجاجى إلى ألوان الطيف

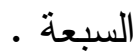
الدهدهان : مادة الكلوروفيل تمنص ضوء الثمس ليتخذى النبات ...
$(V \cdot)$

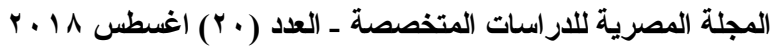


ج... استطاع اسحق نيوتن أن يحلل شعاع الضوء الأبيض عن طريق

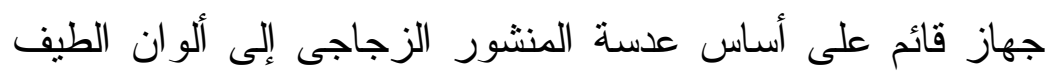

$$
\text { (السبعة . (79) }
$$

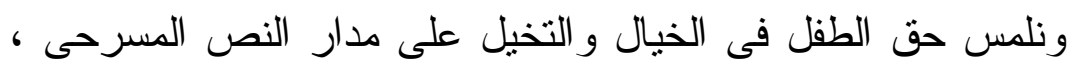

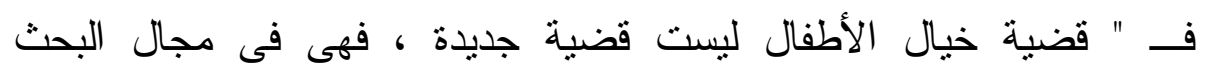

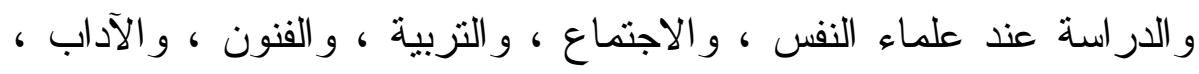

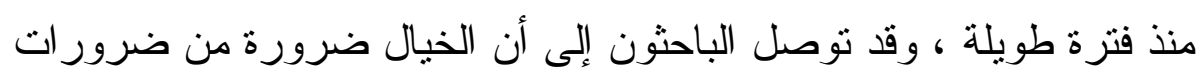

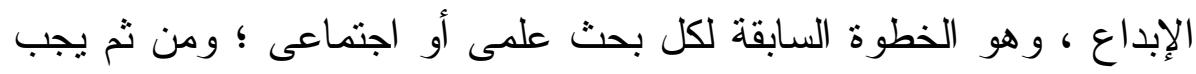

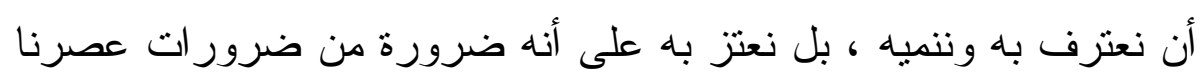

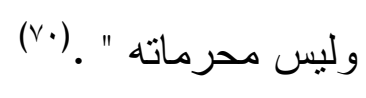

و الخيال يتيح الفرصة للطفل لتكوين الرموز وممارسة اللعب التمنيلى، أو الإيهامى ، ويؤدى إلى التطور المعرفى للطفل ، وتتمية القدرة

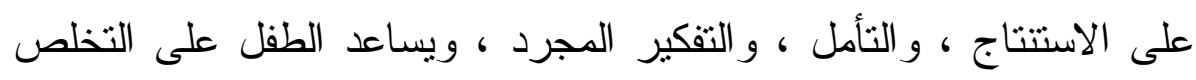

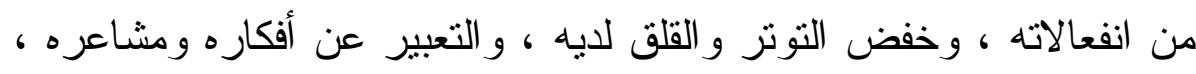

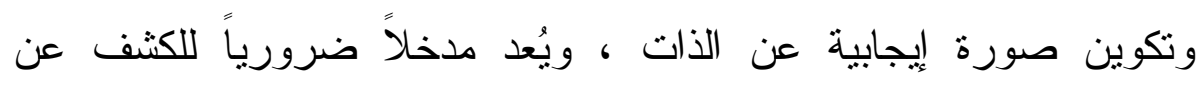

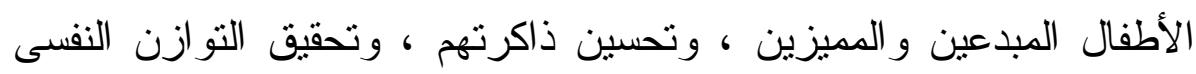

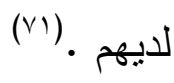
ويرى الباحث أن تنشئة الطفل منذ نعومة أظافره على الخيال

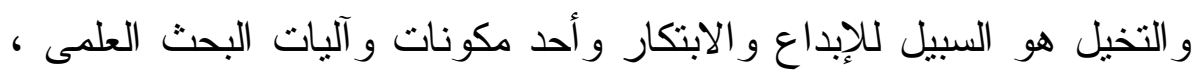
وبذلك يهدف المؤلف من خلال خطابه المسرحى إلى تنشئة جيل مُتعاوِن ولين باحث عن المعلومات وليس مُتلقى لها ونقل العملية العلمية من حالة التعليم

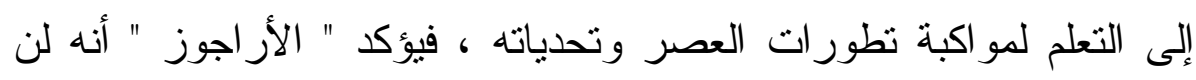

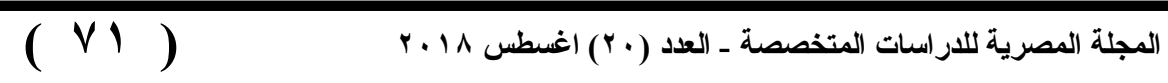


وأومر (السير محمر (لسير

يصل لاختر اعه إلا بمساعدة الجميع وخيالهم وعقولهم ، وكل الاختراعات

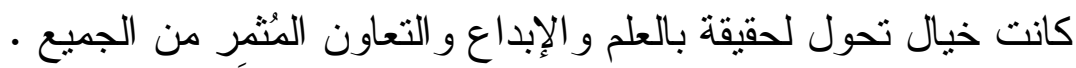
الأراجوز : كل ده خيال .. كل ده مش حقبقى .. ومش هنتوفوا النور الحقيقى اللى بتتخلق منه الألوان إلا لو خلصت اختراعى .. الجبار

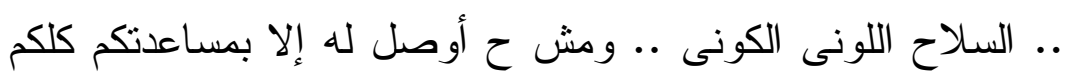

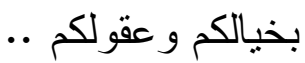
الجميع : كلنا معالك .. ادينا الفرصة .. ادينا فرصة . .

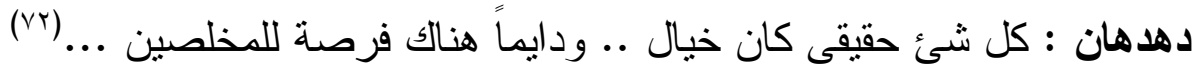

\section{نتائج الدر اسة :}

1- تتاول " سمير عبد الباقى " فى مسرحياته العديد من حقوق الطفل مثل

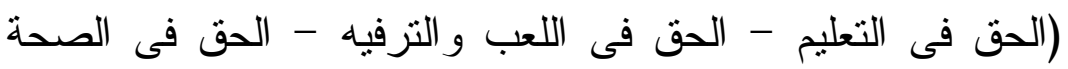
و الغذاء - الحق فى الحماية - الحق فى اختيار السم مناسب - الحق

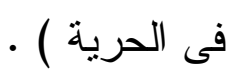

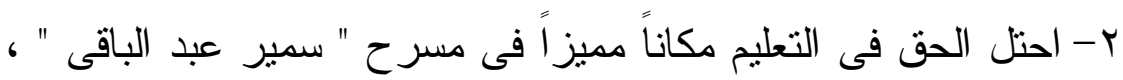

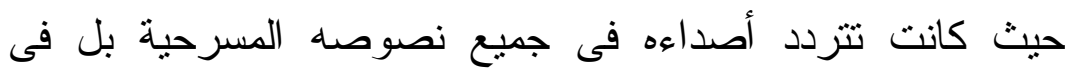

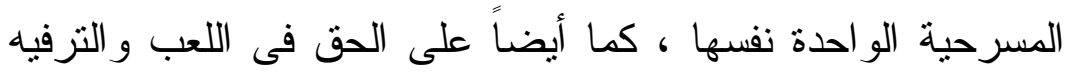
لأهميته وتأثيره الإيجابى على الطفل .

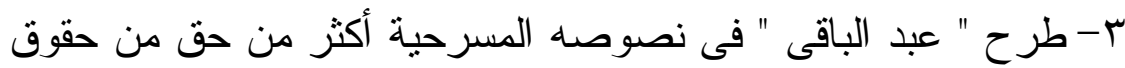

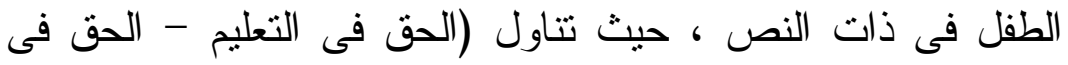

اللعب و الترفيه - الحق فى الصحة والغذاء - الحق فى الحماية الحق فى اختيار اسم مناسب - الحق فى الحرية ) فى مسرحية "

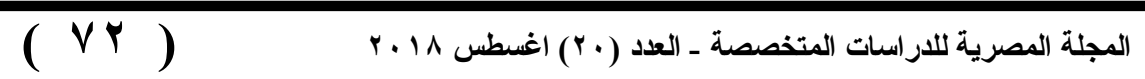




\section{حقوق الطفل فى مسرح "سمير عبد الباقى"}

أحلام سقا " ، وفى كل نص در امى كانت تتردد أصداء أكثر من حق من حقوق الطفل .

ع-وظف المؤلف العناصر المسرحية نوظيفاً فنباً لتحقيق هدفه المنشود

من خطابه المسرحى الموجه للطفل .

0- حرص المؤلف على توظيف شخصية الطفل فى معظم نصوصها

المسرحية ، و إثر الك الأطفال فى الخطاب المسرحى الموجه لأقر انهم

لتو عيتهح وتبصير هم بحقوقهم .

7- أكد " سمير عبد الباقى " على أهية وعى المجتمع بحقوق الطفل ،

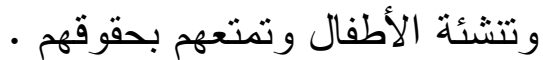

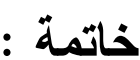

وختاماً ، يؤكد الباحث على الدور التتويرى التوعوى التزبوى التعليمى لمسرح الطفل ، حيث يعتبر واحداً من أبرز تلك الوسائل التربوية و التعليمية ، التي تستخدم في تتمية شخصية الطفل من كافة جو انبها عقلياً

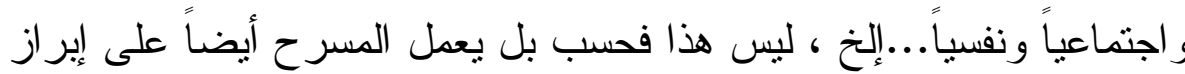
حقوق الطفل للمجتمع و إكساب الطفل الوعى بتلك الحقوق ، وقد تتاول الباحث بالتحليل بعض الأعمال المسرحية للكاتب " سمير عبد الباقى " الذى لفى لابع حرص على طرح بعض حقوق الطفل فى نصوصه المسرحية ، ويؤكد الباحث أن" سمير عبد الباقى " طرح فى مسرحه العديد من حقوق الطفل مثل (الحق فى التعليم - الحق فى اللعب و التزفيه - الحق فى الصحة و الغذاء الحق فى الحماية - الحق فى اختيار اسم مناسب - الحق فى الحرية ) ،

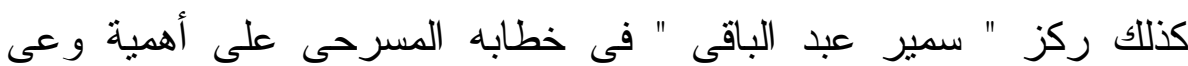
المجتمع بحقوق الطفل ، وتتشئة الأطفال وتمتعهم بحقوقهم .

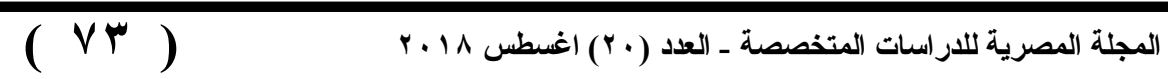




\section{وأُمر (السير ححمر (لسير

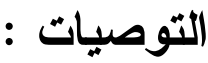

يطرح الباحث فى ضوء الدر اسة الحالية عدة توصيات :

1-ضرورة اهتمام كُناب مسرح الطفل بحقوق الطفل فى أعمالهم

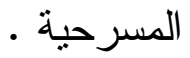

r- اهتمام الدولة بحقوق الطفل بصفة عامة وفى المجال الدرامى

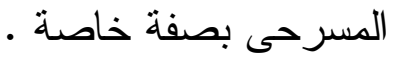

r-نركيز الدر اما المسرحية على حقوق الطفل فى كل مر احل الطفولة

$$
\text { ولا يقتصر على مرحلة دون الأخرى • الأل }
$$

ع- إجر اء العديد من الدراسات و الأبحاث العلمية الأكاديمية للكثف عن هن

حقوق الطفل فى العديد من الكتابات المسرحية للطفل .

(1) فوزى سعد عيسى : أدب الأطفال ( الثعر - مسرح الطفل - القصة ) ، ، دار الوفاء

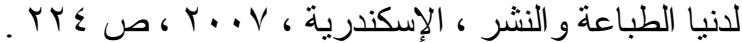

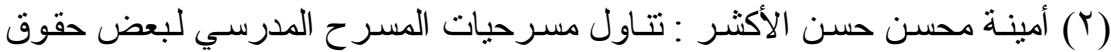

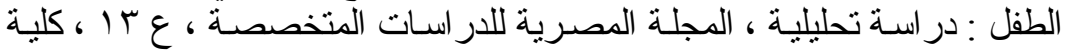

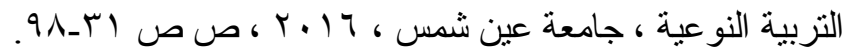

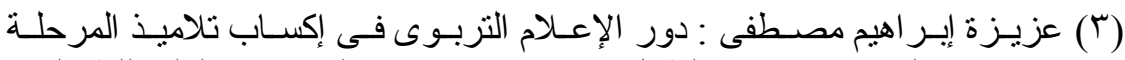

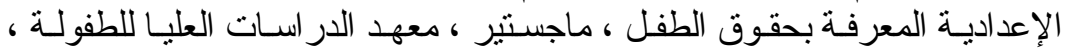

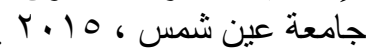

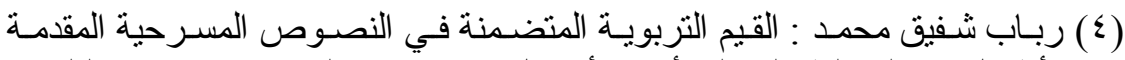

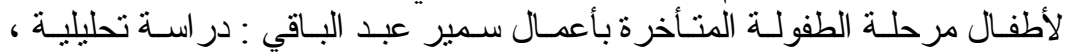

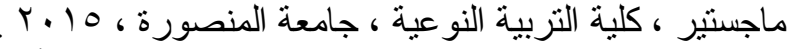

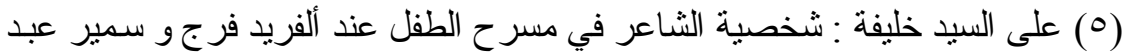

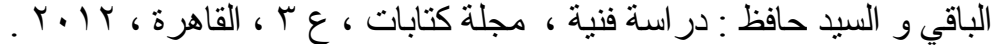

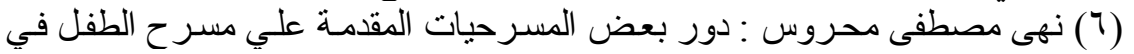

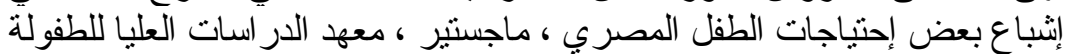

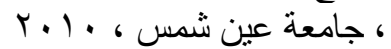

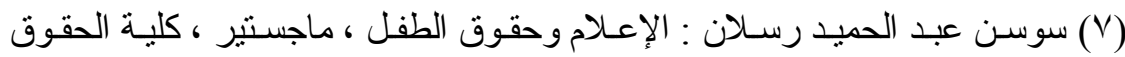

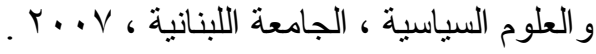


(8) Directory of European Research and Documentation Institutions on Children's Rights, UNESCO, Child watch International ,UNICEF, United Nations Educational, Scientific and Cultural, 1995, P.8.

(9) إبر اهيم حمادة : معجم المصطلحات الدر امية و المسرحية ، دار المعارف ، القاهرة

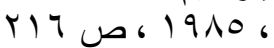

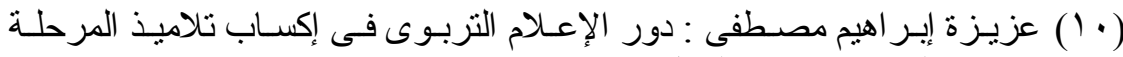

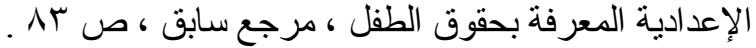

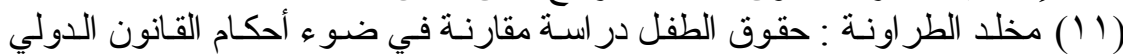

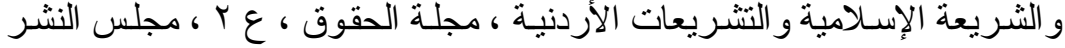

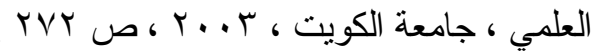

(12) Directory of European Research and Documentation Institutions on Children's Rights, UNESCO, Child watch International ,UNICEF, United Nations Educational, Scientific and Cultural, 1995, P.8.

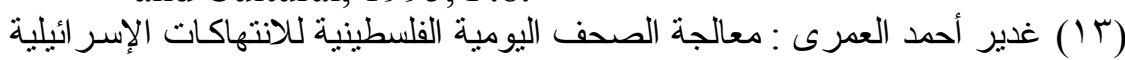

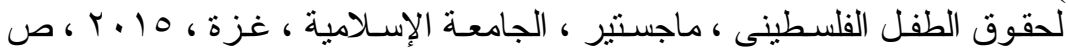

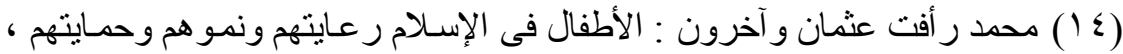

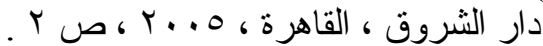

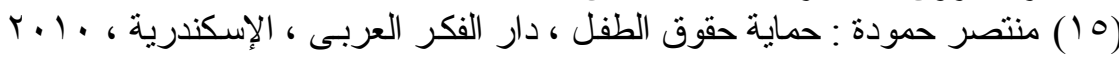

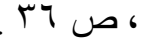

(7 (1) غسان خليل : حقوق الطفل : النطور التاريخي منذ بدايات القرن العشرين ، بغداد

$r \leqslant$ r r...0،

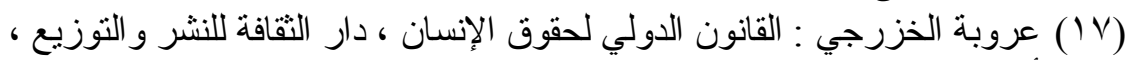

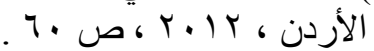

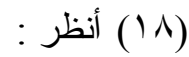

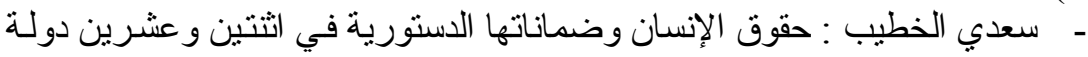

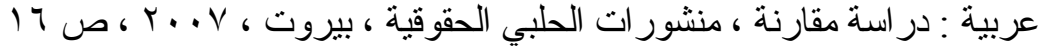

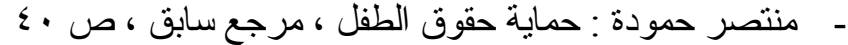

(9 (19) غدير أحمد العمرى : معالجة الصحف اليومية الفلسطينية للانتهاكات الإسر ائيلية الئية

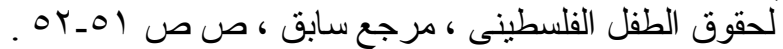

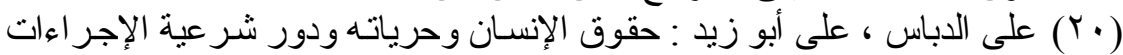

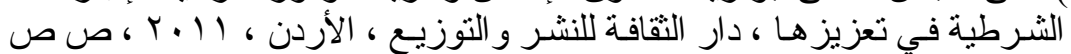

V) - 71

(Y) غدير أحمد العمرى : معالجة الصحف اليومية الفلسطينية للانتهاكات الإسر ائيلية

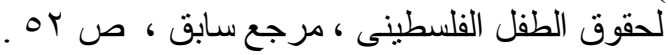

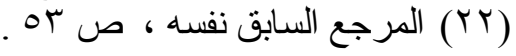




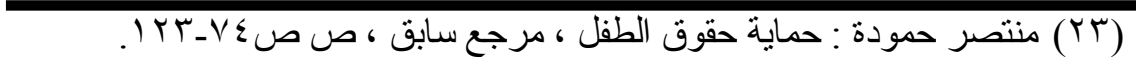

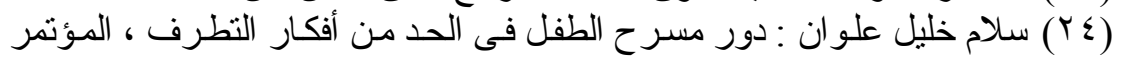

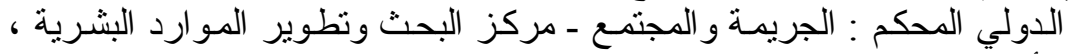

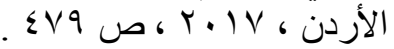

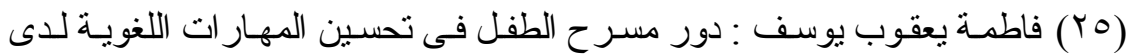

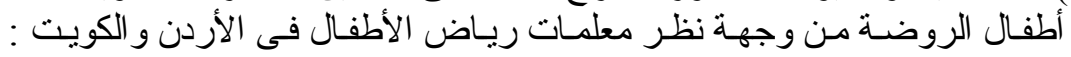

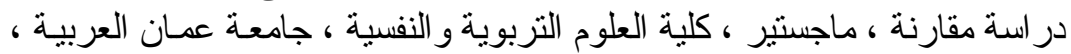

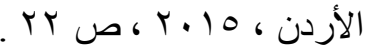

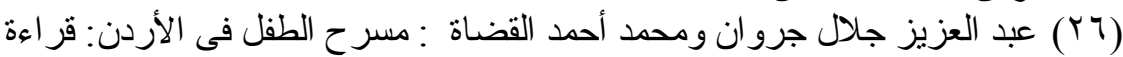

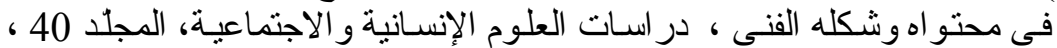

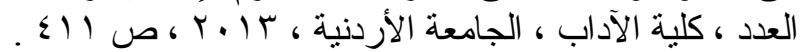

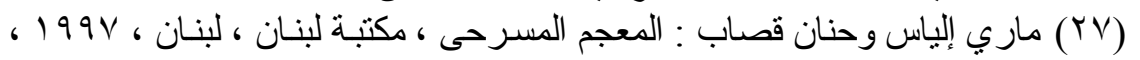

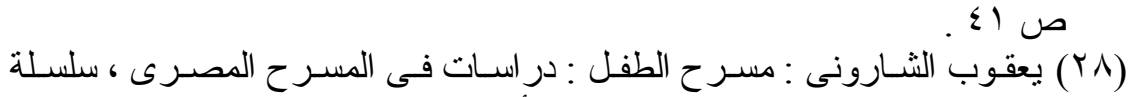

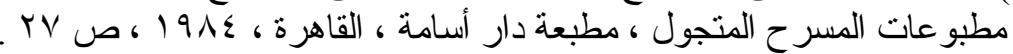

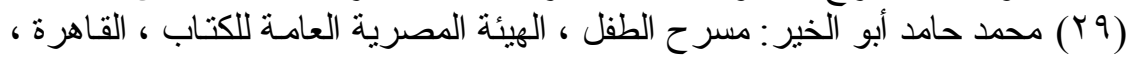

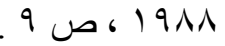

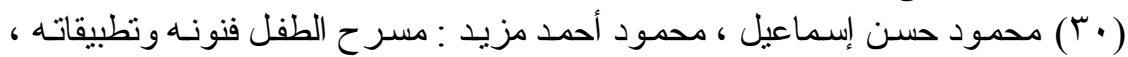

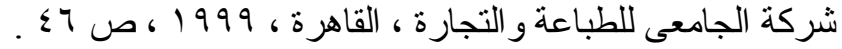

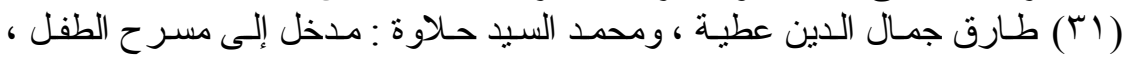

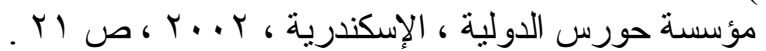

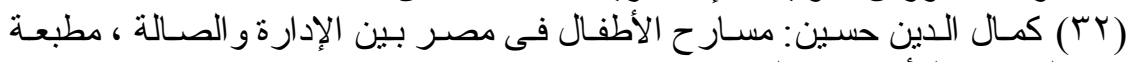

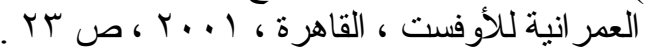

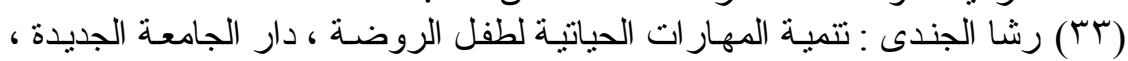

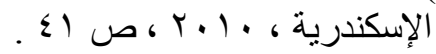

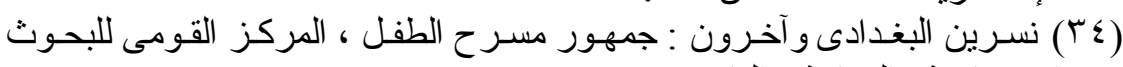

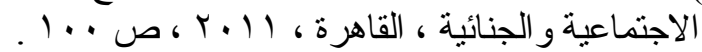

(35) Kathren G. : Counseling Children , Appraotical introduction London, thousand oaks, California, SAGF , 1997: P.18. (דץ؟) كمال الدين حسين: مسار ح الأطفال فى مصر بين الإدارة و الصالة ، مرجع سابق

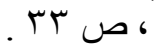

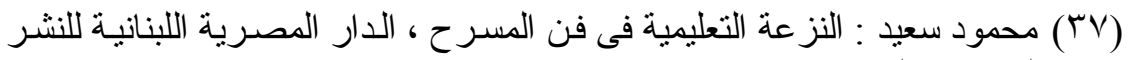

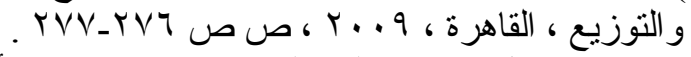

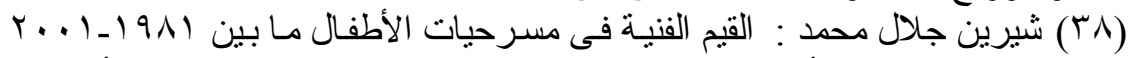

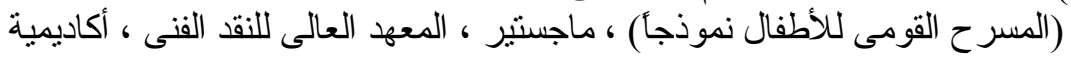

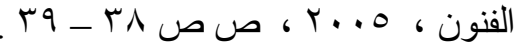

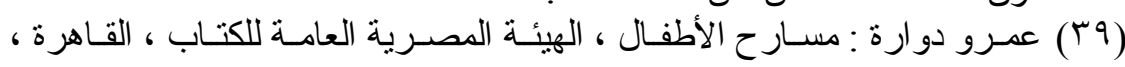

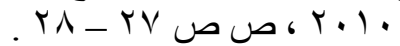




\section{حقوق الطفل فى مسرح "سمير عبد الباقى"}

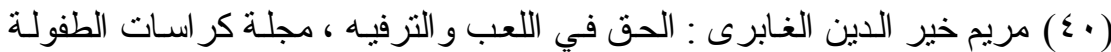

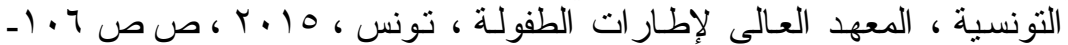

$$
.1 \cdot 1
$$

( أ) سمير عبد الباقى : دفاتز ابن عبد الباقى ـ الدفتز الخامس ـ مسرحيات الأطفال

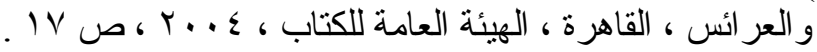

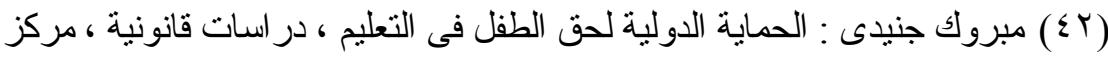

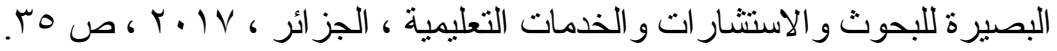

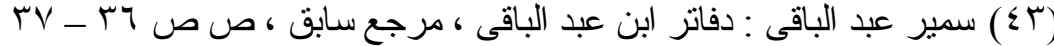

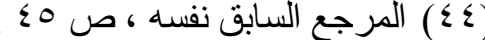

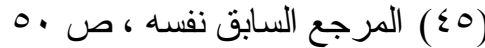

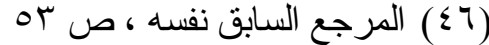

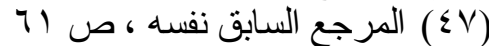

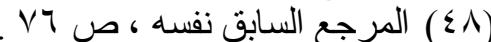

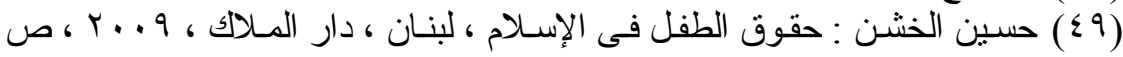

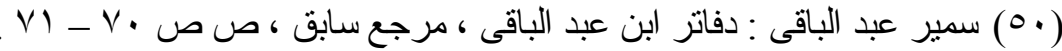

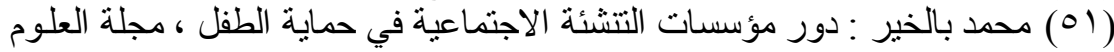

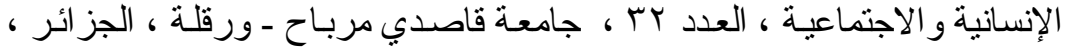

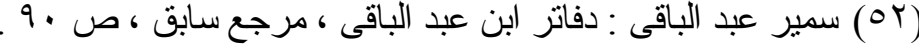

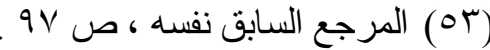

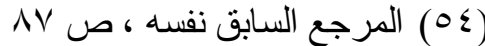

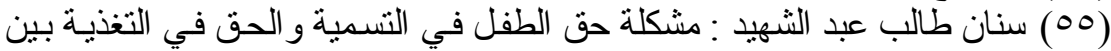

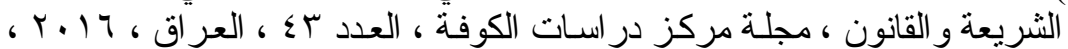

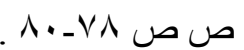

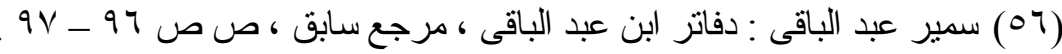

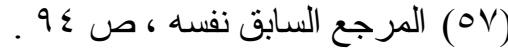

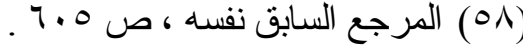

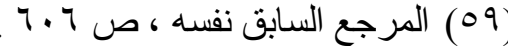

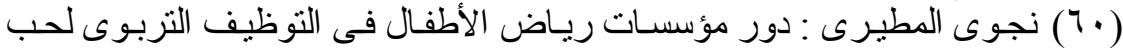

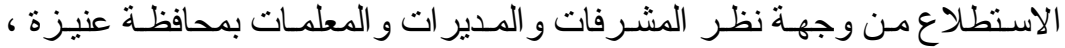

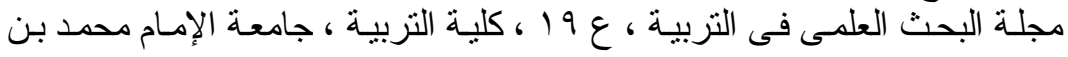

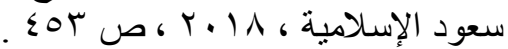

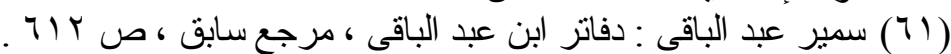

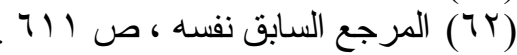

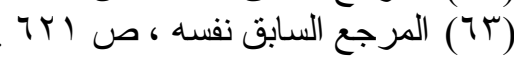

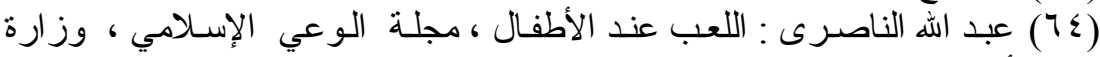

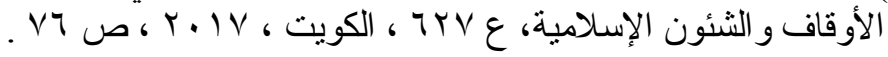




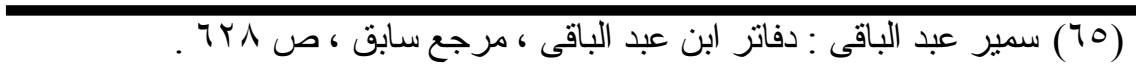

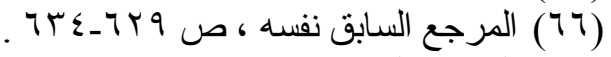

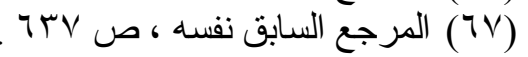

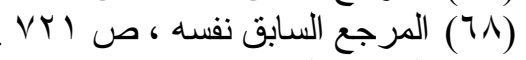

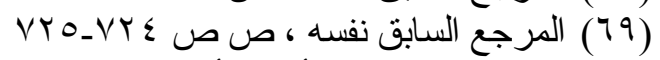

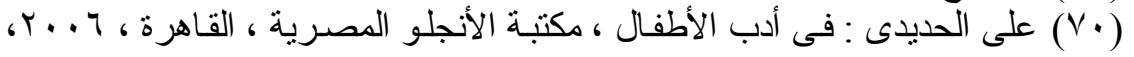

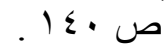

(VI)

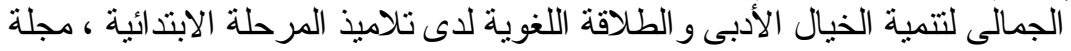

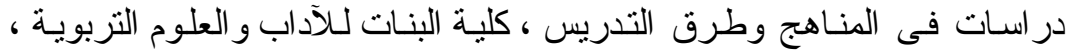

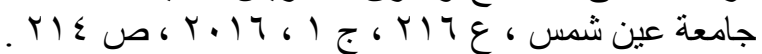

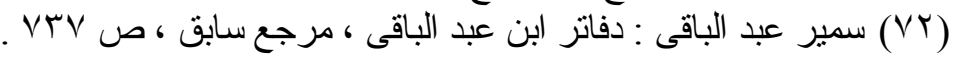

